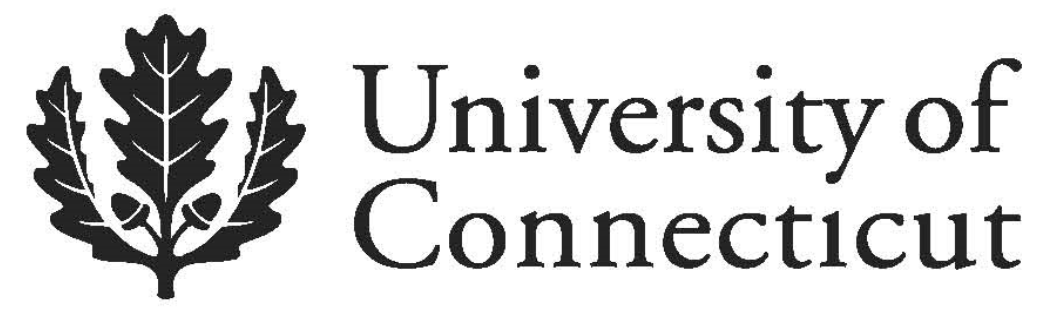

Department of Economics Working Paper Series

Unemployment Rate Hysteresis and the Great Recession: Exploring the Metropolitan Evidence

Girogio Canarella

California State University, Los Angeles

University of Nevada-Las Vegas

Stephen M. Miller

University of Nevada-Las Vegas

University of Connecticut

Stephen K. Pollard

California State University, Los Angeles

Working Paper 2013-19

August 2013

365 Fairfield Way, Unit 1063

Storrs, CT 06269-1063

Phone: (860) 486-3022

Fax: (860) 486-4463

http://www.econ.uconn.edu/

This working paper is indexed on RePEc, http://repec.org 


\title{
Unemployment Rate Hysteresis and the Great Recession: Exploring the Metropolitan Evidence
}

\author{
Giorgio Canarella \\ California State University, Los Angeles \\ Los Angeles, CA 90032 \\ gcanare@calstatela.edu \\ University of Nevada, Las Vegas \\ Las Vegas, Nevada, USA 89154-6005 \\ giorgio.canarella@unlv.edu \\ Stephen M. Miller* \\ University of Nevada, Las Vegas \\ Las Vegas, Nevada, USA 89154-6005 \\ stephen.miller@unlv.edu \\ Stephen K. Pollard \\ Trident University International \\ Cypress, CA 90630 \\ Stephen.Pollard@trident.edu
}

\begin{abstract}
:
This paper explores the mean-reverting behavior of the unemployment rate using monthly geographically disaggregated data for the period 1991:01 through 2012:02. We apply both standard unit-root tests and tests that allow for one and two structural breaks in the mean. We find evidence that favors both unit-root and stationary processes. No series exhibits stationarity around a constant mean, which does not support the traditional natural-rate hypothesis, but about half of the series exhibit stationarity around a shifting mean. For these series, we find that the break occurs at the Great Recession. To complement the unit-root analysis, we also examine the behavior of the series using the Bai and Perron methods to detect multiple regimes at unknown points of time. We find that the Great Recession also altered the persistence of the unemployment rate series over the identified regimes. In general, the values of the estimated persistence within regimes decrease between those regimes, implying faster absorption of shocks later in the sample period.
\end{abstract}

Keywords: structural break tests, hysteresis, Great Recession, unit root, MSA unemployment rate, mean reversion

JEL codes: C22, E24, R10, R23 


\section{Introduction}

Since the seminal paper of Nelson and Plosser (1982), researchers continue to debate whether the unemployment rate follows a mean-reverting or a random walk with drift process. The traditional natural-rate hypothesis, as originally formulated by Phelps (1967) and Friedman (1968), maintains that the unemployment rate fluctuates around a constant long-run equilibrium rate (the natural rate) and that any deviation of the actual unemployment rate from the natural rate dissipates in the long run. As a result, the dynamics of the unemployment rate exhibit a meanreverting, I(0), process. Thus, the need for policy action proves less compelling, since the unemployment rate eventually returns to its equilibrium level. Subsequent developments revise the traditional hypothesis suggesting that the natural rate of unemployment may change over time as a result of changes in the structure of the economy (Phelps, 1994; Phelps and Zoega, 1998). Thus, the structuralist version of the natural-rate hypothesis contends that the unemployment rate fluctuates around a long-run equilibrium level, but this equilibrium level experiences occasional, but persistent, structural changes. As a result, the dynamics of unemployment rate remain an $\mathrm{I}(0)$ process, but a process that reverts to a mean that shifts over time.

In contrast to the traditional and structuralist natural-rate hypotheses, the hysteresis hypothesis (Blanchard and Summers, 1986) questions the existence of a long-run equilibrium level and emphasizes that movements in the unemployment rate exhibit a long-term persistence (Blanchard and Summers, 1987). Shocks that affect the unemployment rate exert permanent effects, shifting the unemployment rate equilibrium from one level to another. Thus, in the hysteresis process, the unemployment rate perpetuates itself, sustained by the erosion of human capital, skill mismatches in the labor market resulting from structural change, disincentive effects 
originating from the welfare system, and insider/outsider processes. ${ }^{1}$ The unemployment rate rises or falls in response to shocks and fails to return to its previous equilibrium level. Consequently, if the hysteresis hypothesis holds, the dynamics of the unemployment rate follows an I(1), a non-stationary, or unit-root ${ }^{2}$ process. A high unemployment rate, if left alone, may persist and constitute a serious problem even in the long run. Thus, the hysteresis hypothesis requires policy measures to return the unemployment rate to its former lower level.

A sizable and growing empirical literature tests for the existence of a unit root in the unemployment rate. The findings prove mixed for European countries. Blanchard and Summers (1986, 1987), Brunello (1990), Mitchell (1993), Jaeger and Parkinson (1994), and Roed (1996), among others, employ conventional univariate unit-root tests to examine unemployment rates in European countries and conclude that these unemployment rates exhibit hysteresis. On the other hand, Arestis and Mariscal (2000) and Papell, et al. (2000) report results that mostly reject the hysteresis hypothesis. Panel unit-root tests reveal results that contradict the univariate tests. For example, Song and Wu (1997, 1998), Lee, et al. (2001), and Camarero and Tamarit (2004) find strong rejections of the hysteresis hypothesis for OECD countries. Empirical findings on US unemployment rates also prove mixed. Mitchell (1993), Breitung (1994), and Hatanaka (1996) find evidence that favors non-stationarity, while Nelson and Plosser (1982), Perron (1988), and Xiao and Phillips (1998) report evidence that favors stationarity.

This paper provides new evidence on the nature and stochastic properties of the unemployment rate dynamics from a sub-national, local standpoint rather than a national

\footnotetext{
${ }^{1}$ Roed (1997) provides an in-depth survey of the theoretical models developed to explain the sources of hysteresis.

${ }^{2}$ Granger (2010) argues that the analysis of bounded, non-stationary, time-series data remains an important unsolved issue. A non-stationary unemployment rate proves problematic, since, strictly speaking, a bounded variable in the interval $[0,1]$ cannot display random-walk movement in the long run. Over relatively short time spans, however, the unemployment rate may follow an untrended I(1) process. See, for example, León-Ledesma and McAdam (2004), and Brunello, et al. (2000).
} 
perspective, although, for comparison purposes, we also apply the analysis to the national unemployment rate. We contribute to the empirical unemployment literature in three ways.

First, we examine the hysteresis hypothesis using unemployment rates measured at the Metropolitan Statistical Area (MSA) level. Metropolitan economies’ boundaries depend on economic and market criteria, unlike regions, states, and counties (Drennan, 2005), and their economic interdependencies cut across jurisdictional boundaries. ${ }^{3}$ Research at the disaggregated MSA level receives little, if any, attention in the literature, ${ }^{4}$ but can offer an important and interesting perspective of the structure of the US labor market. Several reasons justify this approach. One, the labor market dynamics differ across MSAs and, consequently, the national labor market dynamics aggregates heterogeneous local dynamics (Decressin and Fatás, 1995). ${ }^{5}$

Two, MSA-specific shocks probably trigger different adjustment mechanisms than national

\begin{abstract}
${ }^{3}$ As defined by the US Office of Management and Budget, a Metropolitan Statistical Area (MSA) contains a core area with a large population nucleus, together with adjacent communities exhibiting a high degree of economic and social integration with that core. To qualify as an MSA, the geography must contain a core urban area with a population of 50,000 or more.

${ }^{4}$ The vast majority of the existing literature examines the dynamics of the unemployment rate from a national aggregate point of view (i.e., apply unit-root tests to the US unemployment rate). A few analyses use state-level data in conjunction with panel unit-root tests. Song and Wu $(1997,1998)$, using the Levin, et al. (2002) panel unit-root test, find that hysteresis does not characterize the unemployment rate dynamics of the US states. Leon-Ledesma (2002) reach similar conclusions, using the Im, et al. (2003) panel unit-root test. Cheng, et al. (2012), on the contrary, employing the PANIC method that permits cross-sectional dependence between the US states, find strong evidence of hysteresis in state-level data, especially when the tests include the new data from the recent recession. Clemente, et al. (2005) use national and state-level data to construct panels for the nine divisions and four regions considered by the US Census. They provide evidence against a unit root for the US economy and most of the US states. The evidence against a unit root weakens when considering the Census nine divisions, and even weaker when considering the four Census regions. They conclude, therefore, suggesting that the time-series properties of the unemployment rate may depend, among other things, on the assumed level of disaggregation.
\end{abstract}

${ }^{5}$ To ascertain the extent to which changes in the unemployment rate are common to all MSAs, we regress, following Blanchard and Katz (1992), the change in the unemployment rate for each MSA against the change in US aggregate unemployment rate. We find that changes in MSA unemployment rates respond positively and significantly to changes in the national unemployment rate. In two MSAs (Detroit and Miami), the response displays a more than proportional effect; in eleven MSAs (Atlanta, Boston, Cleveland, Dallas, Denver, Las Vegas, Minneapolis, Phoenix, San Diego, San Francisco, and Seattle), the response displays a less than proportional effect; in the remaining MSAs (Charlotte, Chicago, Los Angeles, New York, Portland, and Tampa), the response displays an equiproportional effect. The average adjusted R-square for the unemployment rate regressions equals 0.51 . Hence, on average, only 51 percent of the changes in MSA unemployment rates are common to all areas. Atlanta and Minneapolis exhibit the lowest adjusted R-square (0.34 and 0.38, respectively), while Dallas, San Francisco and Seattle exhibit the highest adjusted R-square $(0.71,0.62$, and 0.62 , respectively). 
shocks. We expect, for example, substantially more migration movements between MSAs in response to MSA-specific shocks than between the US and other countries in response to nationspecific shocks. Three, analyzing only the nationwide unemployment rate may conceal important disparities that exist between unemployment rates at the MSA level. Although the evolution of the unemployment rates in the local level may relate to each other, their movements may also exhibit much different patterns. Differences in population, stocks of human capital, and industrial composition in different regions may prevent national economic shocks from affecting the MSAs in an undifferentiated manner. Even within a highly developed country like the US, large differences in wages, labor force participation rates, and employment rates across local labor markets still exist (see, e.g., Partridge and Rickman, 1995, 1997; Murphy and Payne, 2002). Thus, the analysis of the unemployment rate dynamics at the MSA level proves important not only per se, but also because differences in unemployment rates, together with differences in labor productivity and participation rates, exert a significant influence on inequalities in local per capita income. ${ }^{6}$

Second, we use a sample that incorporates data from the financial crisis of 2007 to 2008 and the resulting recession, where the US economy lost more than 7.5 million jobs, and the unemployment rate peaked at more than 10 percent in 2009, persisting near this level through 2010 and 2011. This represents the most substantial shock to the US unemployment rate since the Great Depression. The Great Recession witnessed the sharp and widespread increase in the unemployment rate across the US. Every metropolitan region experienced significant increases in unemployment and the average MSA saw the unemployment rate nearly double between 2007

\footnotetext{
${ }^{6}$ Drennan, et al. (2004) consider sigma convergence of per capita personal income and average wages for 24 MSAs in the US from 1969 to 2001. They conclude "...income convergence among metropolitan economies is not decreasing.” (p. 583). This finding contradicts the prior literature’s finding of “...convergence in per-capita incomes across U.S. states from 1880 to 1980 is one of the most striking relationships in macroeconomics" (Ganong and Shoag, 2012, p. 2.).
} 
and 2009. Possibly even more important, unemployment duration more than doubled from the previous peak in the post-WWII period. Since the recent crisis in the US labor markets represents a rare event not seen since the Great Depression, the most recent data may highlight alternative ways to view the dynamics of unemployment rates (Cheng, et al., 2012). Accordingly, we explore the role of the Great Recession in defining the stochastic properties of the unemployment series. An open question remains as to whether the Great Recession will leave a permanent mark on the unemployment rate. Did the Great Recession change the underlying stochastic properties of the unemployment rate series in any important way? Did the Great Recession shock cause permanent effects on the unemployment rate, or did the Great Recession shock cause only temporary movements of the unemployment rate around its equilibrium level?

From standard unit-root tests, one concludes that either all shocks cause permanent effects or all shocks dissipate over time. Standard unit-root tests do not allow for the possibility that while most shocks dissipate, a few remain as permanent shocks. These are the shocks generated by structural breaks. The behavior of the US unemployment rate and the MSAs' unemployment rates before and after the Great Recession suggest that the underlying process may experience structural breaks. A structural break in a series biases results towards not rejecting the null hypothesis of a unit root. The potential for structural breaks in economic time series means that constant-parameter unit-root models may not adequately describe their stochastic characteristics. ${ }^{7}$ We implement the unit-root tests of Perron and Vogelsang (1992) and Clemente, et al. (1998), which account, respectively, for single and double shift in the mean of the unemployment series, and are appropriate for non-trending data.

Third, admittedly, no reason exists for restricting the analysis to one or two breaks, as

\footnotetext{
${ }^{7}$ A number of empirical applications of unit-root models of the unemployment rate with structural change exist that establish their empirical relevance over the constant parameter alternatives (Papell, et al., 2000; Arestis and Mariscal, 1999, 2000; Ewing and Wunnava, 2001; Romero-Ávila and Usabiaga, 2007).
} 
reason exists to restrict the analysis only to shifts in the mean. One limitation of unit-root analysis is the assumption of constant persistence. Using an alternative econometric framework, we also examine whether the Great Recession affected the persistence of the unemployment rate. Did the Great Recession change the order of integration of the unemployment rate series, or did persistence before and after the Great Recession remain consistent with a unit root in the unemployment rate? To answer these questions requires that we first measure the persistence of the unemployment rate and to assess whether it changed over time. The persistence of the unemployment rate before and after the Great Recession is of substantial policy interest. ${ }^{8}$ The correct categorization of the unemployment rate series into $\mathrm{I}(0)$ and $\mathrm{I}(1)$ segments, if they exist, proves relevant to adopting the appropriate monetary and fiscal policies. Accordingly, we report the results of tests for discrete breaks in the parameters of AR(1) models fit to metropolitan and aggregate unemployment rates, using the multiple structural breaks model developed by Bai and Perron (1998, 2003).

Our findings yield important new insights into the three outstanding issues in the economics of the unemployment rate. First, using unit-root tests that allow for one and two structural breaks, we find stationarity subject to structural breaks in the level only in about half of the metropolitan unemployment rate series and in the US aggregate. For the remaining series, we find non-stationarity, even after allowing for structural breaks. In other words, MSA unemployment rates revert to a shifting mean in about half of the cases whereas the unemployment rates follow hysteretic behavior in the other half of the MSAs. Second, we find evidence that the unemployment rate shock produced by the Great Recession caused an upward

\footnotetext{
${ }^{8}$ Since employment is an essential condition for most households to meet their financial obligations, rising local unemployment rates can cause rising mortgage defaults and foreclosures. That is, the unemployment rate positively associates with mortgage delinquency (Campbell and Dietrich, 1983), mortgage default (Capozza, et al., 1997; Deng, et al., 2000; Pennington-Cross and Ho, 2010; Quercia, et al., 2012), mortgage default risk (Quercia, et al., 2012), and mortgage foreclosure (Elmer and Seelig, 1999).
} 
structural shift in the underlying mean of all the metropolitan rates as well as the US aggregate. That is, the Great Recession proved a common structural break in all unemployment rate series. Third, we find substantial evidence that the unemployment rate persistence varies markedly over the identified regimes. The unemployment rate series exhibit instability, and this instability manifests itself in both the level and the persistence parameters of the stochastic process. Moreover, these findings also show both changes in persistence within subsamples delimited by the structural breaks of the stationary full-sample region and significant shifts from the fullsample stationary region to stationary subsamples also delimited by structural breaks.

The rest of the paper follows a standard outline. The next section contains a summary of the data. Section 3 reports the findings of various unit-root tests without structural breaks for the unemployment rates of the different MSAs. Section 4 reports the findings of unit-root tests with structural breaks. Section 5 presents estimates of the level of persistence, using the multiple regression model with structural changes proposed by Bai and Perron (1998, 2003). The most significant and consistent finding of this paper is that the Great Recession represents a unique structural change that for many series defines a switching from a non-stationary regime to a stationary regime. Section 6 concludes.

\section{Data and Descriptive Statistics}

We use monthly unemployment rates for twenty MSAs across the US, namely, Atlanta, Boston, Charlotte, Chicago, Cleveland, Dallas, Denver, Detroit, Las Vegas, Los Angeles, Miami, Minneapolis, New York, Phoenix, Portland, San Diego, San Francisco, Seattle, Tampa, and Washington, DC. For comparison purposes, we also include the national unemployment rate. The sample data covers the period from January 1991 to February 2012 (with the exception of Dallas, which starts in January 2000), yielding 254 observations. We measure all unemployment 
rate series in percent. The original seasonally unadjusted data come from the U.S. Department of Labor (Bureau of Labor Statistics). We seasonally adjust the original data, using the X-11 seasonal adjustment procedure. In this regard, we follow most of the extant literature in the field.

Table 1 reports descriptive statistics (mean, maximum, minimum, standard deviation, skewness and kurtosis) and the Jarque-Bera normality statistic for the twenty metropolitan and US unemployment rate series. Detroit and Washington, DC display the highest and lowest unemployment rate averages and standard deviations, respectively. Eight MSAs (Chicago, Cleveland, Detroit, Las Vegas, Los Angeles, Miami, New York, and Portland) possess an average unemployment rate higher than the national rate and five MSAs (Cleveland, Dallas, Minneapolis, New York, and Washington DC) possess an unemployment rate standard deviation less than the national standard deviation. The data display evidence of non-normality with all series recording statistically significant skewness and excess kurtosis. Moreover, we overwhelmingly reject the null hypothesis of normally distributed data, using the Jarque-Bera (1980) test, for all series. The intensity of unemployment rate differences between the twenty MSAs appears evident when we compare the maximum and minimum values of the unemployment rate. Detroit, as expected, displays the highest difference (12.8), followed by Las Vegas (10.9), Charlotte (10.2), and Tampa (9.5). With the exception of Cleveland, Dallas, New York, and Washington, the difference between the maximum and the minimum values in all MSAs exceeds the corresponding difference in the US aggregate rate.

Figure 1 graphs the movement of the unemployment rates for the 20 series as well as for the national aggregate. The different individual series do not behave exactly the same across time. A cursory examination of Figure 1 suggests that most unemployment rate series exhibit at least one structural break. In all series, the striking feature is the sharp response of the 
unemployment rates to the Great Recession. Whether this feature of Figure 1, perceptible in the graphical representation, accounts for a permanent effect on the unemployment rate is not immediately obvious. The visual inspection of the time-series graphs also supports a finding that commonly emerges from empirical studies: unemployment rates appear quite persistent.

\section{Standard Unit-Root Tests}

\subsection{Tests for Unit Roots without Structural Breaks}

We first test for unit roots without accounting for structural changes. Let $U_{t}$ represent the unemployment rate for $t=1,2, \ldots, T$. We specify the data generating process for $U_{t}$ by a firstorder autoregressive process, $\mathrm{AR}(1)$ :

$$
U_{t}=\alpha+\rho U_{t-1}+\varepsilon_{t}
$$

where $\alpha$ and $\rho$ are parameters and $\varepsilon_{t}$ is a Gaussian white-noise error term. Following most of the existing literature (e.g., Roed, 1996; Murray and Papell, 2000; León-Ledesma, 2002), we do not include a time trend in equation (1) because a trend would prove inconsistent with a long-run positive, but non-accelerating, unemployment rate. We capture the persistence of past values of the unemployment rate $U_{t-1}$ on the current value $U_{t}$ by the parameter $\rho$. When $-1<\rho<1$, the unemployment rate is a stationary series evolving towards its steady state value $\mu=\frac{\alpha}{1-\rho}$, and any shock to the unemployment rate dissipates over time. Fluctuations from the natural rate are transitory. If, on the other hand, $\rho=0$, shocks to the unemployment rate show no persistence at all, and the unemployment rate is a white-noise process around the mean $\alpha$. In this case, shocks to local labor markets are completely absorbed within the single period and do not spill over into the next. When $\rho=1$, however, the unemployment rate is a non-stationary time series, and the stochastic process modeled by equation (1) is a unit-root process. Here, shocks cause persistent 
drift and exert permanent effects on the long-run level of the unemployment rate. Since the unemployment rate is a bounded variable, the a priori belief suggests non-stationarity of the unemployment rate. The results of the standard unit-root tests, however, suggest the opposite.

We apply the Augmented Dickey-Fuller (ADF) test (Dickey and Fuller, 1979; Dickey and Fuller, 1981) and the Phillips-Perron (PP) test (Phillips and Perron, 1988) to each MSA unemployment rate series and to the US aggregate unemployment rate. The ADF test for nontrending data uses the following auxiliary regression:

$$
\Delta U_{t}=\alpha+\lambda U_{t-1}+\sum_{j=1}^{k} c_{j} \Delta U_{t-1}+\varepsilon_{t},
$$

where $\Delta U_{t}=U_{t}-U_{t-1}$, and $\lambda=\rho-1$. The null and alternative hypothesis are, respectively, $H_{0}: \lambda=0$ and $H_{1}: \lambda<0$. Rejection of the null hypothesis implies that the unemployment rate reverts to its mean (i.e., stationary around a constant mean). Then, as an alternative, we also implement the Kwiatkowski, et al. (KPSS, 1992) test for the null hypothesis of stationarity. Table 2 reports the findings.

In sum, the results of the ADF, PP, and KPSS tests support the existence of hysteresis in the unemployment rate both at the local and the national levels. These findings imply that the MSA and the US unemployment rate series do not fluctuate around a constant mean. ${ }^{9}$ This, in turn, rejects the traditional natural-rate hypothesis and suggests that metropolitan labor market shocks are not short-lived.

These tests suffer from low power when the autoregressive parameter approaches unity

\footnotetext{
${ }^{9}$ Allowing for a time trend in the data makes the failure to reject the unit-root hypothesis even stronger. The trend variable is generally insignificant, but significant and positive for two unemployment rate series, Charlotte and Minneapolis. One may ask whether the linear trend specification correctly models the behavior of the unemployment rate. Note that the significance of the trend for the Charlotte and Minneapolis disappears when the sample exclude the later years of the Great Recession, which suggests that the trend conceals some changes in the mean in an increasing direction.
} 
(DeJong et al., 1992; Elliot, et al., 1996) and display significant size distortions in the presence of a large negative MA root (Ng and Perron, 1995). Consequently, to address the concerns of low power and size distortions, we also perform the four modified tests (M-tests) developed by Ng and Perron (2001), which address both problems and exhibit maximum power against I(0) alternatives. ${ }^{10}$ These test statistics are modified forms of the Phillips and Perron (1988) $Z_{\alpha}$ and $Z_{t}$ statistics, the Bhargava (1986) $R_{1}$ statistic, and the Elliott, Rothenberg, and Stock (1996) point optimal statistic. Table 3 reports the findings. Once again, individual tests show that we cannot reject the null of a unit root (or, in the case of KPSS, soundly reject the null of stationarity) in the unemployment rate series based on MSA data as well as the US unemployment rate, an average of regional unemployment rate series. ${ }^{11}$ The standard unit-root outcomes indicate that the effect of a shock on MSA unemployment rate will last for a long time, with the negative effects that can impose on the economy.

\subsection{Robustness Checks: Panel Unit-Root Tests}

Due to its potential usefulness, and for completeness, we also test for unit roots in a balanced panel, excluding Dallas. As is well known, panel unit-root tests exhibit the additional benefits of exploiting information contained in the cross-section variation of the series that frequently proves successful in finding evidence of stationarity that does not appear in univariate methods (see, e.g., Camarero, et al., 2006; Christopoulos and León-Ledesma, 2007). We do not find, however, this outcome. The more powerful panel unit-root tests deliver unambiguous evidence that support our univariate results. We cannot reject the panel unit-root null hypothesis by the IPS test (Im, et al., 2003; W-statistic $=-1.075, p$-value $=0.141)$, the Fisher versions of the ADF

\footnotetext{
${ }^{10}$ See Ng and Perron (2001) and Perron and Ng (1996) for a detailed description of these tests.

${ }^{11}$ Our findings differ from those reported in Song and $\mathrm{Wu}$ (1997), who find significant evidence against a unit root in the unemployment rate of 48 US states. Our results do not compare directly with Song and Wu (1997), since they use annual data from 1962-1993.
} 
and PP tests (Maddala and Wu, 1999; ADF-Fisher Chi-square $=40.787, p$-value $=0.435$; PPFisher Chi-square $=14.827, p$-value $=0.999)$, and the Choi versions of the ADF and PP tests (Choi, 2001; ADF-Choi Z-statistic $=-0.875, p$-value $=0.191$; PP-Choi Z-statistic $=2.584, p$ value $=0.995) .{ }^{12}$ Similarly, we reject the joint stationarity hypothesis of the Hadri test (Hadri, 2000; HC Z-statistic $=14.243$, $p$-value $=0.000)$.

Pesaran (2007) shows, however, that these panel unit-root tests prove valid only assuming that the error terms do not exhibit cross-sectional dependence. Independence does not represent a realistic assumption, given that the unemployment rates of different MSAs, especially contiguous MSAs, may correlate contemporaneously. We confirm that cross-sectional dependence exists in our data using a test from Pesaran (2004). Pesaran's CD test rejects the null hypothesis of cross-sectional independence (Chi-square: 152.979, $p$-value $=0.000$ ). Thus, we also implement Pesaran's CADF test (Pesaran, 2007), which also fails to reject the unit root. The CADF test also fails to reject the unit root. Since the $p$-values of the test depend on the lag order, we test the null using 1 to 6 lags. The $p$-values vary from a minimum of 0.190 for lag 1 to a maximum of 0.761 for lag 2.

Finally, we also consider the Nyblom and Harvey (2000) test for common stochastic trends. The Nyblom and Harvey test adopts stationarity under the null. The test, however, possesses the major advantage of incorporating cross-sectional dependence in the panel estimation. Having stationarity of unemployment rates as the null, rather than the alternative, proves desirable because of the difficulty that panel unit-root tests face in deciding whether the natural-rate hypothesis is supported. The findings from this test generally match the substance of the previous findings. The Nyblom and Harvey statistics are, respectively, 39.368 (assuming iid

\footnotetext{
${ }^{12}$ One should exercise some caution in interpreting these results. The null hypothesis states that all the series exhibit unit-root processes, and this hypothesis is violated with even only one stationary series.
} 
RW errors), and 10.082 (allowing for a nonparametric adjustment for the long-run variance with 3 lags). This result remains robust to the choice of the bandwidth parameter ( $m=2,4,6)$. We summarily reject the null hypothesis of zero common trends among all the metropolitan unemployment rate series.

Two possible reasons may explain the failure to reject the unit root in the unemployment rate series. First, these results emerge because the unemployment rate series do contain a unit root and the unemployment rates in the twenty metropolitan regions do follow a hysteretic process. Second, the non-rejection of the unit-root hypothesis may reflect the presence of important structural changes or discontinuities that disguise the stationarity in the series (Perron, 1989; Perron and Vogelsang, 1992). That is, the unemployment rate series may experience structural breaks. If true, then standard stationarity tests can fail to reject the null hypothesis of a unit root. Much evidence exists to show that standard unit-root tests possess poor discriminatory power when applied to time series with structural breaks (Perron, 1989; Zivot and Andrews, 1992; Perron and Vogelsang, 1992; Clemente, et al., 1998; Lee and Strazicich, 2003, 2004). Consequently, the low power of the standard unit-root tests may produce the finding of nonstationarity.

\subsection{Tests for Parameter Instability and Structural Change}

To explore this possibility, we apply the Elliott and Müller (2006) quasi-Local Level test (qLL) to the first-order autoregressive model of the unemployment rates. ${ }^{13}$ The test proves efficient for general persistence in time variation in regression coefficients, and permits single or multiple structural breaks, time-varying parameters, and heteroskedasticity. We adopt the Elliott-Müller test because it does not require a detailed description of the specific form of parameter

\footnotetext{
${ }^{13}$ The use of the first-order autoregressive representation to capture the dynamics of a time series is not without precedents. See, for example, Patton and Timmermann (2012), Stock and Watson (2002), and Diebold and Kilian (2000).
} 
instability. Paye and Timmermann (2006) find that the Elliott and Müller (2006) test exhibits relatively good size properties with a highly persistent explanatory variable. Elliot and Mueller (2006) show that, asymptotically, no power improvement occurs from specifying a typically unknown law of motion. Moreover, the test remains valid for general specifications of the error term and requires no trimming of the data. The test compares the stable regression model with a vector of constant regression parameters $(\beta=\bar{\beta})$ to the unstable alternative where $\beta$ depends on time $\left(\beta=\beta_{t}\right)$. For further details, including the derivation of the test statistic, see Elliott and Müller (2006).

Table 4 reports the results of the Elliott-Müller (2006) test, which rejects the null hypothesis of parameter stability for 18 of the 20 MSA series and for the US series at the 1percent level. For Cleveland and Minneapolis, the exceptions, the test rejects structural stability only at the 5-percent level.

To assess the robustness of these findings, we also apply the Quandt and Andrews SupWald test to consider breaks in both the intercept and the coefficient on the lagged dependent variable (Quandt, 1960; Andrews, 1993b). We use the White heteroskedasticity estimator with finite degree of freedom correction. We compute asymptotic p-values using Hansen (1997) method. Table 5 reports the results of the Sup-Wald test, providing a broadly consistent conclusion as those in Table 4. In particular, we reject the null hypothesis of stability for both the intercept and the coefficient of lagged unemployment rate at the 5-percent level, except for Cleveland and Minneapolis. In addition, the structural break dates identified by the Sup-Wald test concentrate in 2008, except for Cleveland and Minneapolis, where the break date occurs in 2001 and 2006, respectively. Thus, the evidence supports significant persistent time variation. These findings confirm the basic working hypothesis that the MSA unemployment rate series 
conform to stochastic processes contaminated by structural breaks and, thus, provide motivation for further analysis.

\section{Unit-Root Tests and Structural Change}

The unit-root tests reported in Section 3 assume that the data come as realizations of a linear process with no structural discontinuities in the data generating process. If a data series contains structural breaks, conventional tests fail to reject the unit-root hypothesis because they cannot distinguish structural breaks from non-stationarity. The stochastic permanent shifts mimic the effect of a persistent shock. Thus, the non-stationarity identified in the previous section may reflect neglected structural changes (Perron, 1989). When structural breaks exist in the time series, they share features similar to unit-root processes. Visual inspection of the graphs of the unemployment rate series in Figure 1 suggests that this feature forms an important characteristic of the MSA labor markets of the last 20 or so years. A vast literature explains how to model structural breaks when testing for unit roots. Notable studies in this regard include, among others, Zivot and Andrews (1992) and Perron and Vogelsang (1992) single-break unit-root tests, Lumsdaine and Papell (1997) and Clemente, et al. (1998) two-break unit-root tests, and Lee and Strazicich (2003, 2004) minimum Lagrange-Multiplier one- and two-break unit-root tests.

We consider two complementary tests for unit roots in non-trending time series characterized by structural breaks. The possible breaks occur at an unknown time and, therefore, the models estimate the break points endogenously. First, we employ the testing method of Perron and Vogelsang (1992) that allows for a single structural break in the mean. Enders (2004) argues that Perron and Vogelsang unit-root tests are more appropriate for uncertain break dates. Furthermore, Shrestha and Chowdhury (2005) argue that, in the case of a structural break, the testing power of the Perron-Vogelsang unit-root test dominates the Zivot-Andrews (1992) test. 
Second, we employ the Clemente, et al. (1998) testing method, which extends the Perron and Vogelsang approach for non-trending data, to allow for two structural breaks in the mean.

\subsection{Tests for Unit Roots with One Structural Break in the Mean}

Perron and Vogelsang (1992) propose a class of test statistics which entails two singular forms of structural break: the Additive Outlier (AO) model, where structural breaks occur instantaneously, and the Innovational Outlier (IO) model, where changes occur gradually over time. We use the Innovational Outlier (IO) model. Figure 1 shows that the changes in unemployment rates do not occur suddenly, but take place gradually over time. Papell and Prodan (2006) also argue that the Innovational Outlier (IO) proves more appropriate for macroeconomic aggregates. In the Innovational Outlier (IO) case, the Perron-Vogelsang test statistic for the presence of a unit root emerges from estimating the following ADF-type regression for each possible break date:

$$
\Delta U_{t}=\mu+\delta D T B_{t}+d D U_{t}+\rho U_{t-1}+\sum_{t=1}^{k} c_{i} \Delta U_{t-i}+\varepsilon_{t},
$$

where $D U_{t}(=1$, if $t>T B$, and 0 otherwise $)$ is an intercept-shift parameter and $D T B_{t}(=1$, if $t=T B+1$, and 0 otherwise) is a pulse variable. $T B$ represents the break date (i.e., the time period when the mean changes). $T B$ is given by $\lambda T$, where $0<\lambda<1$, implying that the test does not exist at the end points of the sample.

Table 6 displays the results of applying the IO model to test the null of a unit root against the alternative of stationarity around a shifting mean. In stark contrast to the standard unit-root results, the Perron-Vogelsang test significantly rejects more of the unit-root null hypotheses. While the no-break models fail to reject the unit-root null in all twenty metropolitan series and the national series at the 5-percent level, the IO model rejects the null hypothesis of unit root in favor of stationarity with a single mean shift for Las Vegas and Phoenix at the 1-percent level, 
for Charlotte, Chicago, San Francisco, Seattle and Washington at the 5-percent level, and for Boston, Miami, Tampa, and the US aggregate at the 10-percent level. The timing of the break is also important. The Perron-Vogelsang model provides a consistently uniform answer regarding the timing of the structural break. For both the stationary series and the non-stationary series, the break almost uniformly occurs at 2008:3, with the exception of Minneapolis, where the break occurs at 2008:1. The effect of the structural break is positive and significant in all cases, which captures the rise in the mean unemployment rate in the US aggregate and the twenty MSAs rates during the Great Recession. These results suggest that not all shocks exert transitory effects on the unemployment rate, and provide evidence that supports both unit-root and stationary processes subject to a structural break. For the non-stationary MSAs, no reversion to the mean occurs, and all shocks, including the Great Recession, exert permanent effects on the unemployment rate. For the stationary MSAs, most shocks cause temporary movements of the unemployment rate around the equilibrium level, but one shock, the 2008 Great Recession, caused a permanent change in the equilibrium rate.

\subsection{Tests for Unit Roots with Two Structural Breaks in the Mean}

The previous analysis only captures the single most significant break in the unemployment rate series. The behavior of the unemployment rate series over our sample period, however, may include more than a single shift. As Ben-David, et al. (2003) observe, just as the failure to allow for one break can cause the standard unit-root tests to fail to reject the unit-root null, the failure to allow for two breaks, if they exist, can also cause non-rejection of the unit-root null by the tests that only incorporate one break. Following Perron and Vogelsang (1992), Clemente, et al. (1998) develop a unit-root test that allows for two breaks and applies to both the AO and IO models. Clemente, et al. (1998) provide a detailed discussion. 
If the two breaks belong to the IO model, the unit-root hypothesis involves finding the minimum t-ratio on the autoregressive parameter for testing $\alpha=0$ for all break-time combinations of the following model:

$$
\Delta U_{t}=\mu+\delta_{1} D T B_{1 t}+\delta_{2} D T B_{2 t}+d_{1} D U_{1 t}+d_{2} D U_{2 t}+\alpha U_{t-1}+\sum_{i=1}^{k} \theta_{i} \Delta U_{t-i}+e_{t},
$$

where $D U_{i t}\left(=1\right.$, for $i=1,2$, if $t>T B_{i}$, and 0 otherwise) is an intercept-shift parameter and $D T B_{i t}$ (=1, for $i=1,2$, if $t=T B_{i}+1$, and 0 otherwise) is a pulse variable. $T B_{1}$ and $T B_{2}$ represent the time periods when the mean changes. Clemente, et al. (1998) assume, for simplicity, that $T B_{i}$ equals $\lambda_{i} T, 0<\lambda_{i}<1$, which implies that the test does not exist at the end points of the sample, and $\lambda_{2}>\lambda_{1}$, which eliminates those cases where breaks occur in consecutive periods.

The test rejects the null hypothesis of a unit root, if $\alpha$ differs significantly from zero. In this case, the unemployment rate follows a stationary process around the two structural breaks. All but two shocks (the breaks) cause temporary movements of the unemployment rate. On the other hand, if $\alpha$ does not differ significantly from zero, then the unemployment rate follows a non-stationary process and any shock exerts permanent effects on the long-run level of the unemployment rate.

Table 7 records the findings of the Clemente, et al. (1998) test with double mean shifts based on the IO model. We use a 5-percent trimming value and specify the maximum number of lags to 12 . We expect that allowing for possibly two breaks will provide further evidence against the unit-root hypothesis. This occurs only for Los Angeles, where we reject the null hypothesis of unit root at the 5-percent level. This difference in results occurs probably because of the bias from omitting the second break variable, and demonstrates the effect of allowing two breaks instead of one. We reject the null hypothesis of a unit root for Charlotte and Las Vegas at the 1- 
percent level, for Phoenix at the 5-percent level, and for Chicago, Los Angeles, and Washington at the 10-percent level. For San Francisco, Seattle, and Tampa, and the US aggregate, we cannot reject the null of non-stationarity around a double break, but we do reject the unit-root hypothesis in these cases in favor of a stationary unemployment rate with just one break. The tests generally find two structural breaks except for San Francisco and Seattle, where the first break is not significant. What probably causes structural breaks? The two breaks are intuitively appealing because they roughly correspond to the years associated with the recessions of 1991,2000 , and the Great Recession.

The date of the first break varies but clusters in the early and mid-1990s or in the early and mid-2000. Twelve MSA unemployment rate series (Atlanta, Boston, Chicago, Las Vegas, Los Angeles, New York, Phoenix, San Diego, San Francisco, Seattle, Tampa, and Washington, DC) and the US unemployment rate series exhibit a significant structural break in the early to mid-1990s. In all cases, this structural break exhibits a significant negative effect, possibly reflecting the fall in the unemployment rate in the nineties. Thus, not every break associates with a US recession. Six MSA unemployment rate series (Charlotte, Dallas, Denver, Detroit, Miami, Minneapolis, and Portland) experience a significant structural break in the early to mid-2000s, possibly reflecting the recession of early 2000s. The break exhibits a significant positive effect in five MSAs (Charlotte, Denver, Detroit, Minneapolis, and Portland), but a significant negative effect in two series (Dallas and Miami). Only for one MSA (Cleveland) is the first break not significant. The dates of the first break also differ across the metropolitan economies, suggesting that the causes behind the first break probably reflect local and more idiosyncratic factors.

The second break, instead, proves consistently positive and highly significant and, most importantly, occurs during the recent financial crisis and Great Recession. Such structural change 
provides a common ground for the second break in all MSAs. Only two dates occur -- 2008:3 in 16 cases (Boston, Charlotte, Chicago, Cleveland, Dallas, Detroit, Las Vegas, Los Angeles, Miami, Minneapolis, Phoenix, Portland, San Diego, San Francisco, Tampa, and Washington) and the US aggregate, and 2008:8 in four cases (Atlanta, Denver, New York, and Seattle). This almost exact uniformity suggests in the second mean shift during the financial crisis and Great Recession proves the dominate break, since both the Perron and Vogelsang (1992) and Clemente, et al. (1998) unit-root tests generate the same outcome.

These results, as in the single break case, however, also provide evidence that favors both unit-root and stationary processes subject to two structural breaks. This, in turn, suggests that the response of metropolitan labor markets differ. For the non-stationary MSAs, no reversion to the mean occurs, since all shocks, including the Great Recession, exert permanent effects on the unemployment rate. For the stationary MSAs, instead, most shocks produce temporary movements of the unemployment rate around its equilibrium level, but two shocks, one in the nineties and one in 2008, caused two permanent changes in the long-run equilibrium rate. Overall, the combined results of the Clemente, et al. (1998) and Perron and Vogelsang (1992) tests validate the structuralist version of the natural-rate hypothesis for the US and for 12 of the 20 MSAs. In these cases, the unemployment rate reverts to the mean, where the mean moves between regimes (i.e., the unemployment rate reverts to a mean that shifts over time).

Finally, the extent of the mean shift varies across the metropolitan regions, suggesting that metropolitan labor markets responded differentially to the Great Recession. A strong response occurs in Las Vegas, Atlanta, Los Angeles, Chicago and Phoenix while a weak response occurs in Boston, Cleveland, New York, Minneapolis, and Washington, suggesting that the Great Recession exerted a heterogeneous effect on the metropolitan labor markets. In the 
next section, we verify these results using the approach of Bai and Perron (1998, 2003).

\section{Testing for Multiple Regimes}

The prior analysis suggests that the unemployment rate series experienced one or two mean breaks with the dominant break occurring in 2008:03, which coincides with the financial crisis and the Great Recession. Did the Great Recession shift not only the mean but also the persistence of the unemployment rate series? Non-constant persistence is another important feature of economic time series (see Perron, 2006; Kruse, 2010). This section addresses this last question.

Changing persistence in time-series models means that a structural change from nonstationarity to stationarity, or vice versa, occurs over time, implying that the unemployment rate appears stationary during some time periods and follows a unit-root process during others. In such cases, the change does not preserve the stationarity property of the data. Another empirically relevant possibility sees a stable shift in persistence, a structural change of the persistence parameter within the region of stationarity. In such cases, the data generating process proves stationary, I(0), throughout the whole sample, but significant changes in the persistence parameter occurs over the sample. ${ }^{14}$

To maintain consistency with the previous empirical analysis, we adopt a first-order autoregressive model to describe the unemployment rate series, and allow for $m$ structural breaks $(m+1$ regimes) in the level and in the persistence of the series. That is,

$$
U_{t}=\alpha_{j}+\rho_{j} U_{t-1}+\varepsilon_{t}
$$

for $j=1, \ldots, m+1$, and $t=T_{j-1}+1, \ldots, T_{j}$, with the convention that $T_{0}=0$ and $T_{m+1}=T$, where $\alpha_{j}$ and $\rho_{j}$ are the regression coefficients for the $j$ th regime. In this model, the unconditional

\footnotetext{
${ }^{14}$ Changes of persistence in macroeconomic variables occur frequently. Kim (2000) and Leybourne, et al. (2003) review the main literature. Non-constant persistence occurs in inflation (Barsky, 1987; Burdekin and Siklos, 1999), interest rates (Mankiw, et al., 1987), government budget deficits (Hakkio and Rush, 1991), and real output (Delong and Summers, 1988).
} 
mean of the unemployment rate equals $\mu_{j}=\alpha_{j} / 1-\rho_{j}$ and the persistence equals the autoregressive parameter $\left|\rho_{j}\right| \leq 1$. $U_{t}$ is stationary, or mean-reverting, if $\rho_{j}<1$, while $U_{t}$ is a unit-root process, if $\rho_{j}=1$. A structural change occurs when $\alpha_{j+1} \neq \alpha_{j}$ and $\rho_{j+1} \neq \rho_{j}$. Special breaks occur when $\left|\rho_{j}\right|=1$ and $\left|\rho_{j+1}\right|<1$, where the series switches from I(1) to I(0), and when $\left|\rho_{j}\right|<1$ and $\left|\rho_{j+1}\right|=1$, which the series switches from I(0) to I(1).

Equation (5) permits $m$ breaks that manifest themselves by shifts in the intercept and the persistence parameter of the autoregressive process (i.e., all coefficients can change over time). Thus, we test the models as pure structural-change specifications. We explicitly treat the break points as unknown and estimate along with the unknown coefficients. The first break occurs at $T_{1}$ so that the duration of the first regime runs from $t=1$ to $t=T_{1}$ and the duration of the second regime runs from $T_{1}+1$ to $T_{2}$, and so on. Because the $m^{\text {th }}$ break occurs at $t=T_{m}$, the last regime runs from $T_{m}+1$ to $T$, the end of the data set. We note that this model permits breaks in the mean through $\mu_{j}$ and breaks in the persistence through $\rho_{j}$. The unit-root testing approach outlined in the previous sections is more restrictive, since it only permits changes in the level.

Bai and Perron $(1998,2003)$ propose a procedure to test for multiple endogenous structural breaks as well as to identify the number and most likely timing of such breaks. The estimation method considered by Bai and Perron (1998) uses the least-squares principle. Following Perron (1997), but using a modified notation, and considering the case of a pure structural break model where all coefficients can change, we obtain the least squares estimators of $\mu_{j}$ and $\rho_{j}$ for each $m$-partition $\left(T_{1}, \ldots, T_{m}\right)$ by minimizing the sum of the squared residuals: 


$$
\sum_{j=1}^{m=1} \sum_{t=T_{j+1}+1}^{T_{j}}\left[U_{t}-\mu_{j}-\rho_{j} U_{t-1}\right]^{2} .
$$

Let $\hat{\mu}_{j}$ and $\hat{\rho}_{j}$ denote the estimated set of parameters on the given $m$-partition $\left(T_{1}, \ldots, T_{m}\right)$. That is $\hat{\mu}_{j}=\hat{\mu}_{j}\left(T_{1}, \ldots, T_{m}\right)$, and $\hat{\rho}_{j}=\hat{\rho}_{j}\left(T_{1}, \ldots, T_{m}\right)$.

Corresponding to the specific set of parameters $\hat{\mu}_{j}$ and $\hat{\rho}_{j}$ and for an $m$-partition $\left(T_{1}, \ldots\right.$, $\left.T_{m}\right)$, we calculate a minimized sum of squared residuals, denoted as $S_{T}\left(T_{1}, \ldots, T_{m}\right)$, by substituting the values of $\hat{\mu}_{j}$ and $\hat{\rho}_{j}$ into the objective function, equation (6). The estimated break points $\left(\hat{T}_{1}, \ldots, \hat{T}_{m}\right)$ imply that $\left(\hat{T}_{1}, \ldots, \hat{T}_{m}\right)=\arg \min S_{T}\left(T_{1}, \ldots, T_{m}\right)$, where we minimize over all partitions $\left(T_{1}, \ldots, T_{m}\right)$. The estimated regression parameters associate with the $m$-partition $\left(\hat{T}_{1}, \ldots, \hat{T}_{m}\right)$ and correspond to the estimates for each of the respective regimes. Since the break points are discrete parameters and can only assume a finite number of values, we can estimate them by a grid search algorithm. The computational complexity of the conventional grid search algorithm, however, is of the order $O\left(T^{m}\right)$, which represents a formidable task when $m>2$. Bai and Perron (2003) develop an algorithm based on dynamic programming that limits the computational cost to $O\left(T^{2}\right)$ for any number of structural changes $m$.

A number of alternative methods exist for determining the optimal number of breaks. Bai and Perron (1998, 2003) propose three different procedures: (i) the Bayesian Information criterion (BIC) suggested by Yao (1988) and Kim (2000); (ii) the modified BIC criterion discussed by Liu, et al. (1997) (LWZ); and (iii) the sequential procedure (SP). The sequential

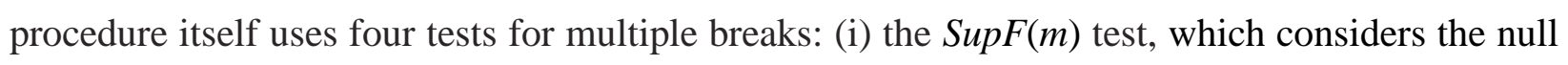
hypothesis of no breaks ( $m=0$ ) versus the alternative of a fixed (arbitrary) number of breaks ( $m$ $=k$ ); (ii) and (iii) two double maximum tests of the null hypothesis of no structural break $(m=0)$ 
versus the alternative of an unknown number of breaks given some upper bound $M(1 \leq m \leq M)$ [the first double maximum test (UD max test) equals a weighted version of the second test (WD max test), applying weights that depend on the number of regressors and the significance level of the test); and (iv) the $\operatorname{SupF}(l+1 \mid l)$ test, which tests sequentially the null hypothesis of $l$ breaks versus the alternative of $l+1$ breaks.

Hall, et al. (2012) note that the information criteria dominate the Bai and Perron (1998) sequential approach, since they directly compare the global minimizers of the sum of squared residuals across different number of breaks. Bai and Perron (1998) acknowledge that a comparison of the respective global minimized sum of squared residuals for $l+1$ and $l$ breaks would work well, but they, nevertheless, employ the $\operatorname{SupF}(l+1 \mid l)$ test due to the tractability of its asymptotic distribution.

Paye and Timmerman (2006) note that cases exist where the sequential procedure selects no breaks when obvious evidence of multiple breaks exists, which is also acknowledged by Bai and Perron (2003). Kim (2000) finds that the BIC detects the true number of breaks accurately even for an integrated DGP of order one. The Bai and Perron (1998) sequential procedure, on the other hand, requires stationarity of the series. Moreover, the data considered in our study exhibit characteristics that differ significantly from the data generating mechanisms considered by Bai and Perron (2006). We know that the unemployment rate exhibits high persistence, and Prodan (2008) shows that the sequential procedure contains serious size distortions with highly persistent data. In particular, it fails to distinguish between persistence and structural breaks.

To circumvent these problems, we approach the question of detecting the optimal number of breaks using the information criteria. Nevertheless, we recognize that information criteria can also lead to poor inference on the number of breaks (Bai and Perron, 2006). Regarding the choice 
of the information criterion, Wang (2006) shows that the BIC performs better than the LWZ. Kruse (2010) finds that in the presence of a lagged dependent variable, the BIC exhibits better properties than LWZ. Bai and Perron (2003) indicate that the BIC works well when actual breaks exist, but less so under the null hypothesis of no breaks. Conversely, the LWZ criterion works better with no actual breaks present, but less so with actual breaks present. We explore the former case, since we possess information, from unit-root analysis, to suggest that breaks do exist. For these reasons, we choose to work with the BIC. For a given model of $m$ breaks, the BIC criterion is defined as follows:

$$
B I C(m)=\ln \hat{\sigma}^{2}(m)+[(m+1) q+m+p] \frac{\ln (T)}{T}
$$

where $m$ is the number of breaks, $q$ is the number of parameters affected by the break, $p$ is the number of parameters not affected by the breaks, and $\hat{\sigma}^{2}(m)=R S S(m) / T$.

In applied work, we need to specify the maximum number of breaks. We allow up to 5 breaks or, equivalently, at most 6 unemployment rate regimes in the sample period. The procedure also requires that we specify the minimum regime size (i.e., the minimum number of observations between breaks). We follow the conventional practice and impose a trimming value 15 percent so that each regime contains at least 15 percent of the observations. ${ }^{15}$ The trimming specification determines the maximum possible number of breaks as well as the minimum regime size. In our case, we set the maximum number of breaks to 5 and allow for a minimum length of 38 months between consecutive breaks. Table 8 reports the number of structural breaks as well as the estimated break dates and their 95-percent confidence intervals using the BIC

\footnotetext{
${ }^{15}$ Trade-offs exist for choosing the appropriate trimming value. Trimming the data too much leaves fewer possible break locations (more observations in each segment), which may omit a true break. On the other hand, trimming the data too little can lead to false break dates appearing at the beginning or end of the sample. A trimming of 15 percent provides a reasonable balance between allowing enough, but not too little, trimming.
} 
criterion. $^{16}$

Bai and Perron (2003, 2006) outline the procedure used for the computation of confidence intervals for the break dates, which relies on an innovative asymptotic framework where the magnitudes of the shifts converge to zero as the sample size increases. The confidence intervals do not lie symmetrically around the break date, which Bai and Perron (2003) note is a property of their method. For most MSAs, the first break date occurs 1993-1994, and the last exactly in 2008. The confidence intervals range from a minimum of 3 months to a maximum of 21 months. Using the BIC criterion, the twenty MSAs markets divide naturally into three groups with one, two, and three structural breaks for the first (Atlanta, Charlotte, Chicago, Las Vegas, Minneapolis, ${ }^{17}$ Phoenix, Tampa, and Washington, DC), second (Boston, Dallas, Detroit, Los Angeles, and Seattle), and third (Cleveland, Denver, Miami, New York, Portland, San Diego and San Francisco) groups, respectively. The US unemployment rate also exhibits three breaks.

Of the thirty-seven breaks detected by the BIC, five take place between 1994:3 and 1994:4 (Cleveland, Los Angeles, Miami, New York, and San Diego); ten occur between 1997 and 2004 (Boston, Cleveland, Dallas, two in Denver, Detroit, New York, two in Portland, San Diego, and two in San Francisco); and twenty-one (including the US aggregate rate) between 2008:2 and 2008:9. Of the latter, nineteen (including the US aggregate rate) occurred exactly in 2008:4, while the remaining two occurred in 2008:2 (Minneapolis), and 2008:9 (Denver). The confidence intervals of the 2008 break prove asymmetric and relatively wide (narrow) at the lower (upper) band, with the exceptions of Las Vegas, Los Angeles, New York, and San Diego,

\footnotetext{
${ }^{16}$ The application of the sequential test $\mathrm{F}(\mathrm{m}+1 / \mathrm{m})$ produces few differences. Specifically, using a 5-percent level, the sequential test suggests one break for all MSAs and the US, with the exception of Los Angeles, for which the test indicates two breaks, and Cleveland and Minneapolis, for which the test fails to detect a structural break.

${ }^{17}$ For Minneapolis, the BIC for zero and one break are identical (i.e., -3.32). We report Minneapolis in the onebreak category, because we note a small, 4-percent reduction in the RSS going from zero to one break.
} 
where we can estimate the break dates with higher precision. Clearly, these findings do not provide a perfect match with the break dates identified in the series using the unit-root approach. In all cases, however, the second break estimated using the Clemente, et al. approach or the onetime break estimated using the Perron and Vogelsang approach fall within the 95-pefrcent confidence intervals of the 2008 break date identified by the BIC. This confirms one more time that the Great Recession exhibits a structural break in the unemployment rate series.

Since the level and persistence of the unemployment rate appear to depend on the regime, we now turn to the question of whether these parameters vary across the regimes. Table 9 reports the results from the estimation of the dynamic model in equation (8) over the identified regimes. Specifically, using OLS (Bai and Perron, 1998), we estimate the model over different regimes demarcated by the structural break(s) identified in Table 8. In these regressions, we use White heteroskedasticity consistent estimator with finite-sample degree of freedom correction. We deduce several interesting points from the findings. ${ }^{18}$

The results of the Bai-Perron OLS estimation indicate that the unemployment rate changes not only in its mean but also in its persistence. In general, the persistence varies noticeably between regimes and across metropolitan areas. In the first group of nine MSAs (Atlanta, Charlotte, Chicago, Las Vegas, Minneapolis, Phoenix, Seattle, Tampa, and Washington) with two regimes, the degree of persistence declines significantly going from the first to the second regime. The confidence intervals on the persistence estimate in the first regime include a unit root, while the confidence intervals of the second regime do not.

In the second group of six MSAs (Boston, Dallas, Detroit, Los Angeles, Minneapolis, and

\footnotetext{
${ }^{18}$ We report least squares estimates and do not attempt to correct the downward bias resulting from the near unitroot problem (Orcutt and Winokur, 1969) using the median unbiased estimator (e.g., Andrews, 1993a; Andrews and Chen, 1994) or the bootstrap bias-corrected estimator (Hansen, 1999; Kim, 2003) because the latter approaches do not explicitly allow for structural breaks (Romero-Ávila and Usabiaga, 2011). Accordingly, our empirical results favor stationarity.
} 
Seattle) with three regimes, the persistence shows a similar pattern. The degree of persistence declines from the first regime to the second regime and then to the third regime for Boston, Dallas, and Seattle. In case of Detroit, and Minneapolis, the second regime shows a lower persistence than the first and the third one, while Los Angeles exhibits a degree of persistence that is lower in the first regime.

Finally, in the third group of seven MSAs (Cleveland, Denver, Miami, New York, Portland, San Diego, and San Francisco) with four regimes, the degree of persistence generally decreases from an extremely high value of 1.220 in case of Denver in the second regime, to a value of 0.782 in case of Miami in the second regime, which is not a particularly high degree of persistence. In the third and fourth regimes, the level of persistence ranges from low values of 0.848 (Cleveland in the third regime) and 0.843 (Denver in the fourth regime) to high values of 0.918 (Cleveland in the fourth regime) and 0.914 (New York and San Diego in the fourth regime). For the aggregate US, the level of persistence goes from 1.00 in the first regime to 0.906 in the second regime, and then to 0.903 and 0.910 in the third and fourth regimes, respectively.

In sum, when we allow for structural change in the level of persistence, the estimate of persistence falls. This finding contrasts not only the results of the unit-root tests with no structural change, but also those of the unit-root tests with structural change. The introduction of structural change in the persistence in the unemployment rates implies a reduction of the levels of persistence. Most interesting, however, is the reduction of the persistence in the regime following the Great Recession. In addition, the differences in persistence across MSAs in the regime following the Great Recession do not significantly differ, which implies that the response of these markets to the Great Recession does not differ much. 


\section{Conclusions}

The past two decades witnessed a growing interest in examining the unemployment rate, since the work of Blanchard and Summers (1987) questioned its stationarity. In this paper, we examine the behavior of the unemployment rate in 20 U.S. Metropolitan Statistical Areas and the US using monthly data over the period 1991:01 to 2012:02 and illustrate the relevance of considering structural breaks in tests of unemployment rate hysteresis. Our findings come to several important conclusions. First, the financial crisis and the Great Recession significantly affected the dynamics of the unemployment rate in our sample of metropolitan economies and the US. Second, no series exhibits stationarity around a constant during the sample period, which does not support the traditional natural-rate hypothesis. Third, unit-root tests that allow for one or two structural breaks do not identify a single, uniform dynamic behavior of the unemployment rate series. Different MSA unemployment rates exhibit different behavior. This, in turn, suggests that the forces that equalize unemployment rates across MSAs are weak, and supports the disequilibrium view of regional unemployment disparities (Armstrong and Taylor, 2000). On the one hand, we find evidence that 12 MSA unemployment rate series and the US national series are well described by a stationary process with one or two breaks. On the other hand, we find evidence of unit-root behavior for the remaining MSAs, even when we account for structural breaks, suggesting that different MSAs respond in differing ways to shocks. For the nonstationary series, no mean reversion occurs and all shocks, including the Great Recession, exert permanent effects on the unemployment rate. In contrast, for the stationary series, the process reverts to the mean, but the mean shifts over time. This implies that while most shocks are shortlived and cause only temporary movements of the unemployment rate around the equilibrium level, some shocks, one of which we identify with the Great Recession, cause a permanent 
change in the equilibrium level. Finally, the results of the multiple regime tests of Bai and Perron $(1998,2003)$ indicate structural changes in the level and the persistence of the series over the identified regimes. In general, the persistence varies noticeably between regimes and across metropolitan areas. Interestingly, the level of persistence of all unemployment rate series, while still remaining relatively high, decreases after the Great Recession. This holds even in cases where the unemployment rate series exhibit unit-root behavior with or without structural breaks over the entire sample. In these cases, it appears that the Great Recession associates with a significant shift from global non-stationarity to locally segmented stationarity.

\section{References:}

Andrews, D. W. K., 1993a. Exactly median-unbiased estimation of first order autoregressive/unit root models. Econometrica 61, 139-165.

Andrews, D. W. K., 1993b. Tests for parameter instability and structural change with unknown change point. Econometrica 61, 821-856.

Andrews, D. W. K., and Chen, H.-Y., 1994. Approximated median-unbiased estimation of autoregressive models. Journal of Business and Economic Statistics, 12, 187-204.

Arestis, P., and Mariscal I., 1999. Unit roots and structural breaks in OECD unemployment. Economics Letters 65, 149-156.

Arestis, P., and Mariscal, I., 2000. OECD Unemployment: Structural breaks and stationarity, Applied Economics 32, 399-403.

Armstrong, H., and Taylor, J., 2000. Regional Economics and Policy, $3^{\text {rd }}$ ed. Oxford: Blackwell Publishers.

Bai, J., and Perron P., 1998. Estimating and testing linear models with multiple structural changes. Econometrica 66,47-78.

Bai, J., and Perron, P., 2003. Computation and analysis of multiple structural-change models. Journal of Applied Econometrics 18, 1-22.

Bai, J., and Perron, P., 2006. Multiple structural change models: a simulation analysis. In Corbae, D., Durlauf, S. N., and Hansen, B. E., (eds.) Econometric Theory and Practice: Frontiers of Analysis and Applied Research, Cambridge: Cambridge University Press, 212-237. 
Barsky, R. B., 1987. The Fisher hypothesis and the forecastibility and persistence of Inflation. Journal of Monetary Economics 19, 3-24.

Ben-David, D., Lumsdaine, R. and Papell, D. H., 2003. Unit root, postwar slowdowns and longrun growth: evidence from two structural breaks. Empirical Economics 28, 303-319.

Bhargava, A., 1986. On the theory of testing for unit roots in observed time series. Review of Economic Studies 53, 369-384.

Blanchard, O., and Summers, L. H., 1986. Hysteresis and the European unemployment problem. In Fisher, S. (ed), NBER Macroeconomics Annual 1986, Cambridge Mass. MIT Press.

Blanchard, O., and Summers, L. H., 1987. Hysteresis in unemployment. European Economic Review 31, 288-295.

Blanchard, O., and Katz, L. F., 1992. Regional evolutions. Brookings Papers on Economic Activity 1, 1-75.

Breitung, J., 1994. Some simple tests of the moving average hypothesis. Journal of Time Series Analysis 15, 351-370.

Brunello, G., 1990. Hysteresis and the Japanese unemployment problem: A preliminary investigation. Oxford Economic Papers 42, 483-500.

Brunello, G., Lupi, C., and Ordine, P., 2000. Regional disparities and the Italian NAIRU. Oxford Economic Papers 52, 146-177.

Burdekin, R. C. K., and Siklos, P. L. 1999. Exchange rate regimes and shifts in inflation persistence: Does nothing else matter? Journal of Money, Credit and Banking 31, 235247.

Camarero, M., Carrion-i-Silvestre, J. L., and Tamarit, C., 2006. Testing for hysteresis in unemployment in OECD countries: New evidence using stationarity panel tests with breaks. Oxford Bulletin of Economics and Statistics 68, 167-182.

Camarero, M., and Tamarit, C., 2004. Hysteresis vs. natural rate of unemployment: new evidence for OECD countries. Economic Letters 84, 413-417.

Campbell, T. S., and Dietrich, J. K., 1983. The determinants of default on insured conventional residential mortgage loans. The Journal of Finance 37, 1569-1581.

Capozza, D. R., Kazarian, D., and Thomson, T. A., 1997. Mortgage default in local markets. Real Estate Economics 25, 631-655.

Cheng, K. M., Durmaz, N., Kim, H., and Stern, M., 2012. Hysteresis vs. natural rate of US unemployment. Economic Modelling 29, 428-434. 
Choi, I., 2001. Unit root tests for panel data. Journal of International Money and Finance 20, 249-272.

Christopoulos, D. C., and León-Ledesma, M. A., 2007. Unemployment hysteresis in EU countries: what do we really know about it? Journal of Economic Studies 34, 80-89.

Clemente, J., Lanaspa, F., and Montañés, A. 2005., The unemployment structure of the US States. Quarterly Review of Economics and Finance 45, 848-868.

Clemente, J., Montañés, A., and Reyes, M., 1998. Testing for Unit Roots in Variables with a Double Change in the Mean. Economics Letters 59, 175-182.

DeJong, D. N., Nankervis, J. C., Savin, N. E., and Whiteman, C. H., 1992 Integration versus trend stationarity in time series. Econometrica 60, 423-433.

DeLong, J. B., and Summers, L. H., 1988. How does macroeconomic policy affect output? Brookings Papers on Economic Activity 2, 433-494.

Decressin, J., and Fatás, A., 1995. Regional labor market dynamics in Europe. European Economic Review 39, 1627-1655.

Deng, Y., Quigley, J. M., and Van Order, R., 2000. Mortgage terminations, heterogeneity and the exercise of mortgage options. Econometrica 68, 275-308.

Diebold, F. X., and Kilian, L., 2000. Unit root tests are useful for selecting forecasting models. Journal of Business and Economic Statistics 18, 265-273.

Dickey, D. A., and Fuller, W. A., 1979. Distribution of the estimators for autoregressive time series with a unit root. Journal of the American Statistical Association 74, 427-431.

Dickey, D. A., and Fuller, W. A., 1981. Likelihood ratio statistics for autoregressive time series with a unit root. Econometrica 49, 1057-1072.

Drennan, M. P., 2005. Possible sources of wage divergence among metropolitan areas of the United States. Urban Studies 42, 1609-1620.

Drennan, M. P., Lobo, J., and Strumsky, D., 2004. Unit root tests of sigma income convergence across us metropolitan areas. Journal of Economic Geography 4, 583-595.

Elliott, G., and Müller, U. K., 2006. Efficient tests for general persistent time variation in regression coefficients. Review of Economic Studies 73, 907-940.

Elliot, G., Rothenberg, T. J., and Stock, J. H., 1996. Efficient tests for an autoregressive unit root, Econometrica 64, 813-836. 
Elmer, P. J., and Seelig. S. A., 1999. Insolvency, trigger events, and consumer risk posture in the theory of single-family mortgage default. Journal of Housing Research 10, 1-25.

Enders, W., 2004. Applied Econometric Time Series. Wiley.

Ewing, B. T., and Wunnava, P. V., 2001. Unit roots and structural breaks in North American unemployment rates. North American Journal of Economics and Finance 12, 273-282.

Friedman, M., 1968. The role of monetary policy. American Economic Review 58, 1-17.

Ganong, P., and Shoag, D., 2012. Why Has Regional Income Convergence in the U.S. Stopped? (March 28, 2013). HKS Working Paper No. RWP12-028. Available at SSRN: http://ssrn.com/abstract=2081216 or http://dx.doi.org/10.2139/ssrn.2081216

Granger, C. W. J., 2010. Some thoughts on the development of cointegration. Journal of Econometrics 158, 3-6.

Hadri, K., 2000. Testing for unit roots in heterogeneous panel data. Econometrics Journal 3, 148-161.

Hall, A. R., Osborn, D. R., and Sakkas, N. D., 2012. The asymptotic expectation of the residual sum of squares in linear models with multiple break points. Discussion paper, Department of Economics, University of Manchester, Manchester UK.

Hansen, B. E., 1997. Approximate asymptotic p values for structural-change tests. Journal of Business and Economic Statistics 15, 60-67.

Hansen, B. E., 1999. The grid bootstrap and the autoregressive model. The Review of Economics and Statistics 81, 594-607.

Hakkio, C., and Rush, M., 1991. Is the budget deficit too large? Economic Inquiry 29, 429-445.

Hatanaka, M., 1996. Time-Series-Based Econometrics, Oxford University Press.

Im, K. S., Pesaran, M. H., and Shin, Y., 2003. Testing for unit roots in heterogeneous panels, Journal of Econometrics 115, 53-74.

Jaeger, A., and Parkinson, M., 1994. Some evidence on the hysteresis of unemployment rates. European Economic Review 38, 329-342.

Kim, J., 2000. Detection of change in persistence of a linear time series. Journal of Econometrics 95, 97-116.

Kim, J., 2003. Forecasting autoregressive time series with bias-corrected parameter estimators International Journal of Forecasting, 19, 493-502. 
Kruse, R., 2010. Forecasting trending autoregressive time series under changing persistence, Working Paper, Aarhus University.

Kwiatkowski, D., Phillips, P. C. B., Schmidt, P., and Shin, Y., 1992. Testing the null hypothesis of stationarity against the alternative of a unit root. Journal of Econometrics 54, 159-178.

Lee, J., and Strazicich, M. C., 2003. Minimum Lagrange multiplier unit root test with two structural breaks. Review of Economics and Statistics 85, 1082-1089.

Lee, J., and Strazicich, M. C., 2004. Minimum LM unit root test. Working Paper, Department of Economics, Appalachian State University.

Lee, J., Strazicich, M. C., and Tieslau, M., 2001. Hysteresis in unemployment data. Evidence from panel unit root tests with structural change. Working Paper www.econ.unt.edu/research/pdf/0108McsStruct.pdf

León-Ledesma, M. A., 2002. Unemployment hysteresis in the US states and the EU: A Panel approach. Bulletin of Economic Research 54, 95-103.

León-Ledesma, M. A., and McAdam, P., 2004. Unemployment, hysteresis and transition. Scottish Journal of Political Economy 51, 377-401.

Levin, A., Lin, C. F., and Chu, C. S. J., 2002. Unit root tests in panel data asymptotic and finitesample properties. Journal of Econometrics 108, 1-24.

Leybourne, S. J., Kim, T., Smith, V., and Newbold, P., 2003. Tests for a change in persistence against the null of difference-stationarity. Econometrics Journal 6, 291-311.

Liu, J., Wu, S., and Zidek, J. V., 1997. On Segmented multivariate regressions. Statistica Sinica. 7, 497-525.

Lumsdaine, R. L., and Papell, D. H., 1997. Multiple trend breaks and the unit root hypothesis. Review of Economics and Statistics 79, 212-218.

Maddala, G. S., and Wu, S., 1999. A comparative study of unit root tests with panel data and a new simple test. Oxford Bulletin of Economics and Statistics 61, 631-652.

Mankiw, N. G., Miron J., and Weil D., 1987. The adjustment of expectations to a change in regime: A study of the founding of the Federal Reserve. The American Economic Review 77, 358-374.

Mitchell, W. F., 1993. Testing for unit roots and persistence in OECD unemployment rates, Applied Economics 25, 1489-1501.

Murphy, K. J., and Payne J. E., 2002. Explaining change in the natural rate of unemployment: A regional approach. Quarterly Review of Economics and Finance 190, 1-24. 
Murray, C. J., and Papell, D. H., 2000. Testing for unit roots in panels in the presence of structural change with an application to OECD unemployment. In Baltagi, B. H., (ed.) Nonstationary Panels, Panel Cointegration and Dynamic Panels (Advances in econometrics 15). Amsterdam: JAI Press, 223-238.

Nelson, C., and Plosser, C., 1982. Trends and random walks in macroeconomic time series. Journal of Monetary Economics 10:139-162.

Ng, S., and Perron, P., 1995. Unit root tests in ARMA models with data-dependent methods for the selection of the truncation lag. Journal of the American Statistical Association 90, 268-281.

Ng, S., and Perron, P., 2001. Lag length selection and the Construction of Unit Root Tests with Good Size and Power. Econometrica 69, 1519-1554.

Nyblom, J., and Harvey, A., 2000. Tests of common stochastic trends. Econometric Theory 16, 176-199.

Orcutt, G. H., and Winokur, H. S., 1969. First order autoregression: inference, estimation, and prediction. Econometrica 37, 1-4.

Papell, D. H., Murray, C. J., and Ghiblawi, H., 2000. The structure of unemployment. Review of Economics and Statistics 82, 309-15.

Papell, D. H., and Prodan, R., 2006. Additional evidence of long run purchasing power parity with restricted structural change. Journal of Money, Credit and Banking 38, 1329-1349.

Partridge, M. D., and Rickman, D. S., 1995. Differences in state unemployment rates: The role of labor and product market structural shifts. Southern Economic Journal 62, 89-106.

Partridge, M. D., and Rickman, D. S., 1997. The dispersion of U.S. state unemployment rates: The role of market and non-market factors. Regional Studies 31, 593-606.

Patton, A. J., and Timmermann, A., 2012. Forecast rationality tests based on multi-horizon bounds. Editor's invited paper. Journal of Business and Economic Statistics 30, 1-17.

Paye, B. S., and Timmermann, A., 2006. Instability of return prediction models. Journal of Empirical Finance 13, 274-315.

Pennington-Cross, A., and Ho, G., 2010. The termination of subprime hybrid and fixed-rate mortgages. Real Estate Economics 38, 399-426.

Perron, P., 1988. Trends and random walks in macroeconomic time series: Further evidence from a new approach. Journal of Economic Dynamics and Control 12, 297-332. 
Perron, P., 1989. The great crash, the oil price shock and the unit root hypothesis. Econometrica $57,1361-1401$.

Perron, P., 1997. Further evidence on breaking trend functions in macroeconomic variables. Journal of Econometrics 80, 355-385.

Perron, P., 2006. Dealing with structural breaks. In Patterson, K., and Mills, T. C., (eds.) Palgrave Handbook of Econometrics. Palgrave Macmillan, 278-352.

Perron, P., and Ng, S., 1996. Useful modifications to unit root tests with dependent errors and their local asymptotic properties. Review of Economic Studies 63, 435-465.

Perron, P., and Vogelsang, T. J., 1992. Nonstationarity and level shifts in a time series with a changing mean. Journal of Business and Economic Statistics 10, 301-320.

Pesaran, M. H., 2007. A simple panel unit root test in the presence of cross section dependence, Journal of Applied Econometrics 22, 265-312.

Pesaran, M. H., 2004. General diagnostic tests for cross section dependence in panels. CESifo Working Papers No.1233.

Phelps, E. S., 1967. Phillips curves, expectations of inflation and optimal unemployment over time. Economica 34, 254-281.

Phelps, E. S., 1994. Structural Slumps: The Modern Equilibrium Theory of Unemployment ,Interest, and Assets. Harvard University Press.

Phelps, E., and Zoega, G., 1998. Natural rate theory and OECD unemployment. Economic Journal 108, 782-801.

Phillips, P. C. B., and Perron, P., 1988. Testing for a unit root in time series regression. Biometrika 75, 335-346.

Prodan, R., 2008. Potential pitfalls in determining multiple structural changes with an application to purchasing power parity. Journal of Business and Economic Statistics 26, 50-65.

Quandt, R., 1960. Tests of the hypothesis that a linear regression obeys two separate regimes. Journal of the American Statistical Association 55, 324-330.

Quercia, R. G., Pennington-Cross, A., and Tian, C. Y., (2012), Mortgage default and prepayment risks among moderate- and low-income households. Real Estate Economics 40, 159-198.

Romero-Ávila, D., and Usabiaga, C., 2007. Unit root tests, persistence, and the unemployment rate of US states. Southern Economic Journal 73, 698-716. 
Roed, K., 1996. Unemployment hysteresis - macro evidence from 16 OECD countries, Empirical Economics 21, 589-600.

Roed, K., 1997. Hysteresis in unemployment. Journal of Economic Surveys 11, 389-418.

Shrestha, M. B., and Chowdhury, K., 2005. A sequential procedure for testing unit roots in the presence of structural break in time series data, Working Paper, Department of Economics, University of Wollongong, http://ro.uow.edu.au/commwkpapers/112.

Song, F. M., and Wu, Y., 1997. Hysteresis in unemployment: Evidence from 48 U.S. states. Economic Inquiry 35, 235-43.

Song, F. M., and Wu, Y., 1998. Hysteresis in unemployment: Evidence from OECD countries. The Quarterly Review of Economics and Finance 38,181-92.

Stock, J. H., and Watson, M. W., 2002. Macroeconomic forecasting using diffusion indexes. Journal of Business and Economic Statistics 20, 147-162.

Wang, Z., 2006. The joint determination of the number and the type of structural changes. Economics Letters 93, 222-227.

Xiao, Z., and Phillips, P. C. B., 1998. An ADF coefficient test for a unit root in ARMA models of unknown order with empirical applications to the U.S. economy. The Econometrics Journal 1, 27-43.

Yao, Y. C., 1988. Estimating the number of change-points via Schwarz criterion. Statistics and Probability Letters 6, 181-189.

Zivot, E., and Andrews, D. W. K., 1992. Further evidence on the great crash, the oil-price shocks, and the unit-root hypothesis. Journal of Business and Economic Statistics 10, 251-270. 
Figure 1: Monthly MSA and US Unemployment Rates (seasonally adjusted) 1991:01 to 2012:02
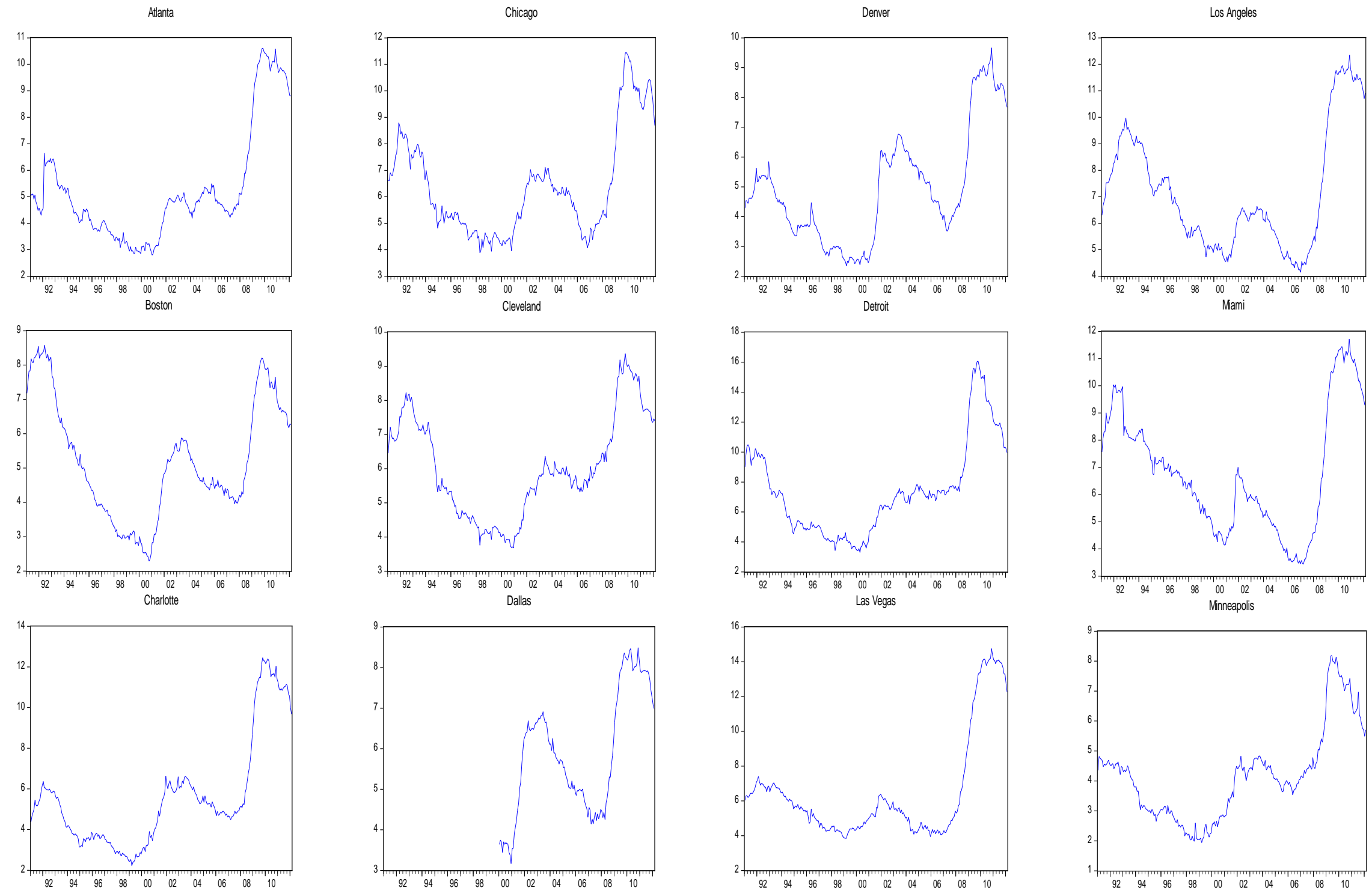

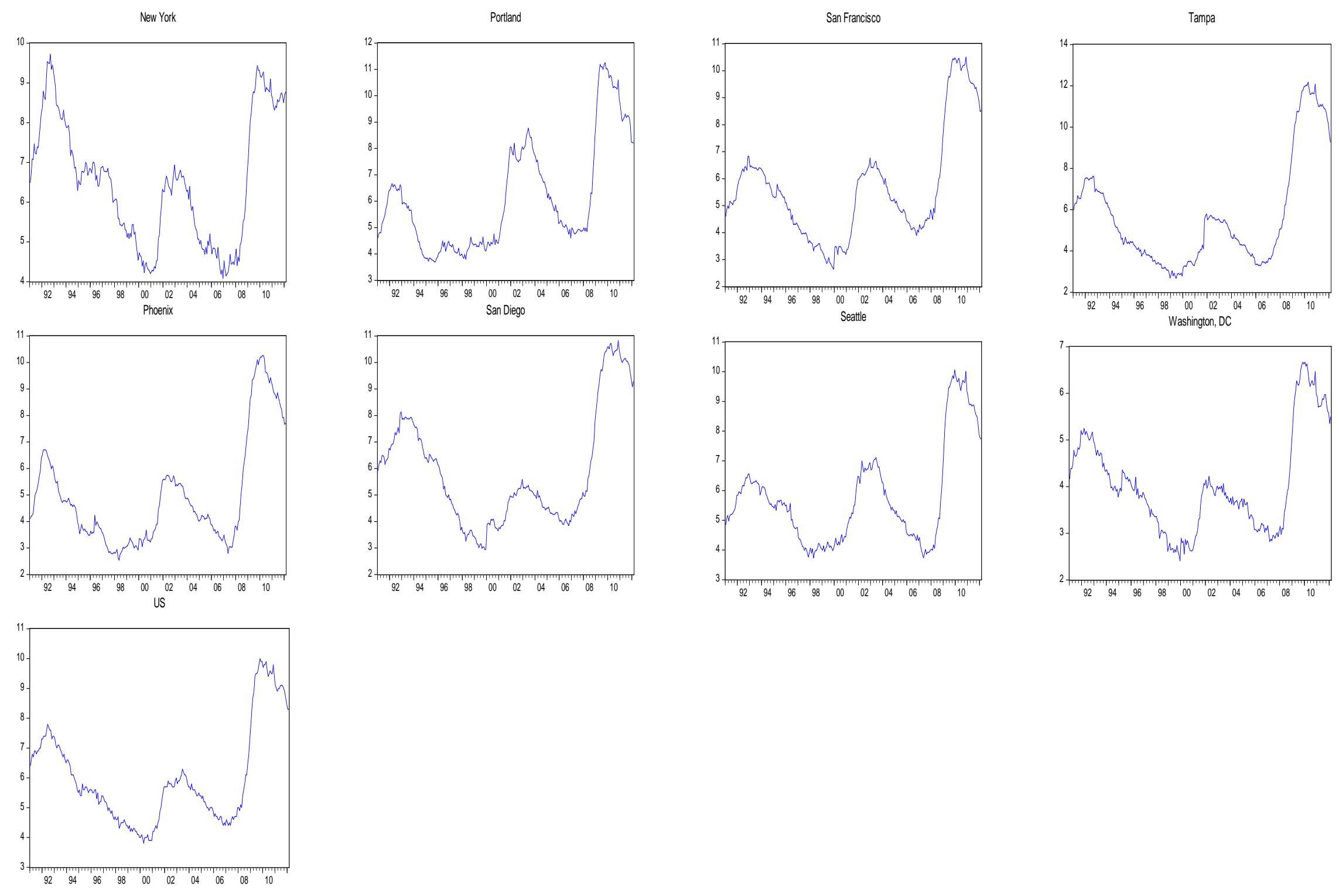
Table 1: $\quad$ Sample Properties of the Data

\begin{tabular}{|c|c|c|c|c|c|c|c|}
\hline MSA & Mean & Max & Min & Std. Dev. & Skewness & Kurtosis & $\begin{array}{c}\text { Jarque- } \\
\text { Bera }\end{array}$ \\
\hline Atlanta & 5.284 & 10.608 & 2.797 & 2.125 & 1.315 & 3.659 & 77.786 \\
\hline Boston & 5.226 & 8.580 & 2.289 & 1.706 & 0.328 & 2.090 & 13.331 \\
\hline Charlotte & 5.628 & 12.452 & 2.222 & 2.674 & 1.253 & 3.621 & 70.529 \\
\hline Chicago & 6.405 & 11.449 & 3.880 & 1.919 & 0.927 & 2.942 & 36.420 \\
\hline Cleveland & 6.046 & 9.370 & 3.679 & 1.470 & 0.352 & 2.195 & 12.098 \\
\hline Dallas & 5.874 & 8.490 & 3.166 & 1.490 & 0.140 & 1.864 & 8.333 \\
\hline Denver & 4.947 & 9.666 & 2.343 & 1.885 & 0.736 & 2.689 & 23.967 \\
\hline Detroit & 7.431 & 16.063 & 3.296 & 3.078 & 1.031 & 3.505 & 47.655 \\
\hline Las Vegas & 6.511 & 14.764 & 3.850 & 3.061 & 1.672 & 4.458 & 140.816 \\
\hline Los Angeles & 7.168 & 12.351 & 4.145 & 2.252 & 0.761 & 2.435 & 27.882 \\
\hline Miami & 6.802 & 11.719 & 3.443 & 2.258 & 0.474 & 2.196 & 16.344 \\
\hline Minneapolis & 4.183 & 8.184 & 1.940 & 1.508 & 0.860 & 3.326 & 32.449 \\
\hline New York & 6.502 & 9.727 & 4.079 & 1.582 & 0.269 & 1.922 & 15.358 \\
\hline Phoenix & 4.980 & 10.264 & 2.529 & 2.027 & 1.191 & 3.430 & 62.029 \\
\hline Portland & 6.127 & 11.262 & 3.692 & 2.088 & 0.919 & 2.771 & 36.322 \\
\hline San Diego & 5.901 & 10.830 & 2.925 & 2.147 & 0.830 & 2.632 & 30.627 \\
\hline San Francisco & 5.658 & 10.513 & 2.643 & 2.006 & 0.981 & 3.254 & 41.454 \\
\hline Seattle & 5.776 & 10.064 & 3.725 & 1.664 & 1.055 & 3.293 & 48.004 \\
\hline Tampa & 5.672 & 12.175 & 2.664 & 2.618 & 1.173 & 3.281 & 59.115 \\
\hline Washington & 4.052 & 6.669 & 2.404 & 1.074 & 0.778 & 2.779 & 26.149 \\
\hline U.S. & 6.018 & 10.000 & 3.880 & 1.641 & 0.951 & 2.932 & 38.318 \\
\hline
\end{tabular}

Note: Jarque-Bera test statistic has a $\chi^{2}$ distribution with 2 degrees of freedom. The critical value at 5-percent level for 2 degrees of freedom is 5.99 . 
Table 2: $\quad$ Unit-root tests: Augmented Dickey-Fuller (ADF) tests, Phillips-Perron (PP) tests and Kwiatkowski-Phillips-Schmidt-Shin (KPSS) tests

\begin{tabular}{lccc}
\hline MSA & ADF & PP & KPSS \\
\hline Atlanta & 0.745 & 0.552 & $1.681^{*}$ \\
Boston & $-2.843^{* * *}$ & -1.539 & $0.656^{* *}$ \\
Charlotte & -2.172 & -0.767 & $1.915^{*}$ \\
Chicago & -1.534 & -1.251 & $0.925^{*}$ \\
Cleveland & -1.199 & -1.030 & $1.012^{*}$ \\
Dallas & -2.224 & -1.599 & $0.833^{*}$ \\
Denver & -1.408 & -1.048 & $1.605^{*}$ \\
Detroit & -1.548 & -1.276 & $1.507^{*}$ \\
Las Vegas & -2.171 & -0.167 & $1.268^{*}$ \\
Los Angeles & -1.161 & -0.830 & $0.676^{* *}$ \\
Miami & -1.502 & -1.196 & $0.627^{* *}$ \\
Minneapolis & -1.109 & -0.963 & $1.819^{*}$ \\
New York & -1.737 & -1.331 & $0.619^{* *}$ \\
Phoenix & -1.591 & -1.230 & $1.161^{*}$ \\
Portland & -1.947 & -1.556 & $1.609^{*}$ \\
San Diego & -1.369 & -0.648 & $0.846^{*}$ \\
San Francisco & -1.640 & -1.061 & $1.163^{*}$ \\
Seattle & 2.208 & -1.494 & $0.916^{*}$ \\
Tampa & -2.237 & -0.789 & $1.131^{*}$ \\
Washington & -1.324 & -1.225 & $0.712^{* *}$ \\
U.S. & & & \\
\hline Note: The & -1.040 & $0.856^{*}$ \\
\hline & -1.398 & $a 19$ & $-2.873 * 20$ \\
\hline
\end{tabular}

Note: $\quad$ The critical values of the ADF test with an intercept and no trend are $-3.457,-2.873$ and -2.573 at $1 \%, 5 \%$ and $10 \%$ levels. The critical values of the PP test are $-3.436,-2.864$ and -2.568 at $1 \%, 5 \%$ and $10 \%$ levels. The critical values of the KPSS test are $0.739,0.463$, and 0.347 at $1 \%, 5 \%$, and $10 \%$ levels. The symbols *, ** and *** denote significance at the 1,5 and $10 \%$ levels, respectively. 
Table 3: $\quad$ Ng-Perron M-Tests Results

\begin{tabular}{lcccc}
\hline MSA & $\mathbf{M Z}_{\alpha}$ & $\mathbf{M Z}_{\mathbf{t}}$ & $\mathbf{M S B}$ & MPT \\
\hline Atlanta & -1.181 & -0.512 & 0.433 & 13.079 \\
Boston & -1.932 & -0.975 & 0.504 & 12.593 \\
Charlotte & -1.018 & -0.447 & 0.439 & 13.699 \\
Chicago & -3.804 & -1.287 & 0.338 & 6.508 \\
Cleveland & -2.469 & -1.065 & 0.431 & 9.679 \\
Dallas & -0.748 & -0.429 & 0.573 & 19.629 \\
Denver & -2.331 & -0.856 & 0.367 & 9.198 \\
Detroit & -3.009 & -1.214 & 0.403 & 8.116 \\
Las Vegas & -0.165 & -0.079 & 0.480 & 17.738 \\
Los Angeles & -1.518 & -0.592 & 0.389 & 11.201 \\
Miami & -3.267 & -1.224 & 0.374 & 7.455 \\
Minneapolis & -2.343 & -1.000 & 0.426 & 9.948 \\
New York & -4.429 & -1.343 & 0.303 & 5.797 \\
Phoenix & -2.835 & -0.988 & 0.348 & 8.122 \\
Portland & -3.085 & -1.089 & 0.352 & 7.716 \\
San Diego & -1.597 & -0.676 & 0.423 & 11.771 \\
San Francisco & -1.853 & -0.719 & 0.388 & 10.461 \\
Seattle & -3.534 & -1.160 & 0.328 & 6.941 \\
Tampa & -2.000 & -0.848 & 0.424 & 10.773 \\
Washington & -3.829 & -1.264 & 0.330 & 6.492 \\
& & & & \\
U.S. & -2.984 & -1.106 & 0.370 & 7.985 \\
\hline Note: See & -509 &
\end{tabular}

Note: $\quad$ See Ng and Perron (2001) for details. The critical values of the $\mathrm{MZ}_{\alpha}$ test with an intercept and no trend are 13.8, 8.1 and 5.7 at $1 \%, 5 \%$ and $10 \%$ levels. The $\mathrm{MZ}_{\mathrm{t}}$ critical values are 2.58 , 1.98 , and 1.62 at $1 \%, 5 \%$ and $10 \%$ levels . The MSB critical values are $0.174,0.233$, and 0.275 at $1 \%, 5 \%$ and $10 \%$ levels . The MPT critical values are 1.78, 3.17 and 4.45 at $1 \%, 5 \%$ and $10 \%$ levels. The symbols $*, * *$ and $* * *$ denote significance at the 1,5 and $10 \%$ levels, respectively. 
Table 4: $\quad$ Elliott-Müller Test Results

\begin{tabular}{lclc}
\hline MSA & Test Statistics & MSA & Test Statistics \\
\hline Atlanta & $-14.391^{*}$ & Minneapolis & $-9.539^{* *}$ \\
Boston & $-17.893^{*}$ & New York & $-13.367^{*}$ \\
Charlotte & $-16.981^{*}$ & Phoenix & $-22.690^{*}$ \\
Chicago & $-11.217^{*}$ & Portland & $-15.643^{*}$ \\
Cleveland & $-11.027^{* *}$ & San Diego & $-21.968^{*}$ \\
Dallas & $-20.914^{*}$ & San Francisco & $-21.040^{*}$ \\
Denver & $-12.100^{*}$ & Seattle & $-16.176^{*}$ \\
Detroit & $-15.500^{*}$ & Tampa & $-24.490^{*}$ \\
Las Vegas & $-24.909^{*}$ & Washington, DC & $-11.208^{*}$ \\
Los Angeles & $-20.652^{*}$ & & $-18.565^{*}$ \\
Miami & $-12.686^{*}$ & U.S. & \\
\hline Note: The critical values of the test are tabulated in Elliott and Müller (2006). * 1-percent (-11.05); ** 5- &
\end{tabular}


Table 5: $\quad$ Andrews Sup-Wald Test for Stability of the AR Model

\begin{tabular}{lccc}
\hline MSA & Sup-Wald F-Statistic & p-value & Break date \\
\hline Atlanta & 29.259 & 0.000 & $2008: 11$ \\
Boston & 26.169 & 0.000 & $2008: 05$ \\
Charlotte & 35.453 & 0.000 & $2008: 05$ \\
Chicago & 22.466 & 0.000 & $2008: 05$ \\
Cleveland & 10.534 & 0.076 & $2001: 01$ \\
Dallas & 27.870 & 0.000 & $2008: 10$ \\
Denver & 25.800 & 0.000 & $2009: 01$ \\
Detroit & 12.286 & 0.036 & $2008: 05$ \\
Las Vegas & 58.625 & 0.000 & $2008: 10$ \\
Los Angeles & 77.002 & 0.000 & $2008: 11$ \\
Miami & 32.764 & 0.000 & $2008: 10$ \\
Minneapolis & 10.427 & 0.079 & $2006: 06$ \\
New York & 71.094 & 0.000 & $2008: 12$ \\
Phoenix & 90.640 & 0.000 & $2008: 05$ \\
Portland & 17.359 & 0.004 & $2008: 05$ \\
San Diego & 50.515 & 0.000 & $2008: 12$ \\
San Francisco & 32.978 & 0.000 & $2008: 10$ \\
Seattle & 29.385 & 0.000 & $2008: 10$ \\
Tampa & 33.672 & 0.000 & $2008: 07$ \\
Washington & 34.339 & 0.000 & $2008: 10$ \\
U.S. & & & \\
\hline Not The & 0.000 & $2008: 10$ \\
\hline
\end{tabular}

Note: $\quad$ The Quandt and Andrews Sup-Wald test tests for a break in both the intercept term and the coefficient on the lagged dependent variable (Quandt, 1960; Andrews, 1993b). We use the White heteroskedasticity estimator with finite degree of freedom correction and the Hansen (1997) method to compute asymptotic $p$-values. 
Table 6: Perron-Vogelsang Test Results for the Innovative Outlier (IO) Model

\begin{tabular}{|c|c|c|c|c|c|}
\hline MSA & TB & DU & Test Statistic & Constant & Lag \\
\hline Atlanta & 2008:3 & $\begin{array}{c}0.287 \\
(4.001)\end{array}$ & $\begin{array}{c}0.048 \\
(3.749)\end{array}$ & 0.214 & 2 \\
\hline Boston & 2008:3 & $\begin{array}{c}0.062 \\
(2.381)\end{array}$ & $\begin{array}{l}-0.024 \ddagger \\
(-3.962)\end{array}$ & 0.108 & 7 \\
\hline Charlotte & 2008:3 & $\begin{array}{c}0.25816 \\
(3.963)\end{array}$ & $\begin{array}{c}-0.042 * * \\
(-4.546)\end{array}$ & 0.191 & 7 \\
\hline Chicago & 2008:3 & $\begin{array}{c}0.226 \\
(3.807)\end{array}$ & $\begin{array}{c}-0.054 * * \\
(-4.472)\end{array}$ & 0.300 & 9 \\
\hline Cleveland & 2008:3 & $\begin{array}{c}0.093 \\
(2.577)\end{array}$ & $\begin{array}{c}-0.032 \\
(-3.222)\end{array}$ & 0.172 & 11 \\
\hline Dallas & 2008:3 & $\begin{array}{c}0.114 \\
(3.020)\end{array}$ & $\begin{array}{c}-0.045 \\
(-3.794)\end{array}$ & 0.242 & 3 \\
\hline Denver & 2008:3 & $\begin{array}{c}0.138 \\
(3.121)\end{array}$ & $\begin{array}{c}-0.296 \\
(-3.272)\end{array}$ & 0.127 & 3 \\
\hline Detroit & 2008:3 & $\begin{array}{c}0.256 \\
(3.330)\end{array}$ & $\begin{array}{c}-0.034 \\
(-3.592)\end{array}$ & 0.207 & 3 \\
\hline Las Vegas & 2008:3 & $\begin{array}{c}0.356 \\
(4.576)\end{array}$ & $\begin{array}{l}-0.052 * \\
(-5.587)\end{array}$ & 0.268 & 10 \\
\hline Los Angeles & 2008:3 & $\begin{array}{c}0.155 \\
(3.394)\end{array}$ & $\begin{array}{c}-0.024 \\
(-3.262)\end{array}$ & 0.154 & 3 \\
\hline Miami & 2008:3 & $\begin{array}{c}0.196 \\
(3.599)\end{array}$ & $\begin{array}{c}-0.035 \neq \\
(-3.892)\end{array}$ & 0.195 & 12 \\
\hline Minneapolis & 2008:1 & $\begin{array}{c}0.149 \\
(3.063)\end{array}$ & $\begin{array}{c}-0.046 \\
(-3.575)\end{array}$ & 0.166 & 9 \\
\hline New York & 2008:3 & $\begin{array}{c}0.105 \\
(2.876)\end{array}$ & $\begin{array}{c}-0.031 \\
(-3.494)\end{array}$ & 0.184 & 7 \\
\hline Phoenix & 2008:3 & $\begin{array}{c}0.206 \\
(4.543)\end{array}$ & $\begin{array}{c}-0.04739 * \\
(-5.406)\end{array}$ & 0.195 & 7 \\
\hline Portland & 2008:3 & $\begin{array}{c}0.153 \\
(3.284)\end{array}$ & $\begin{array}{c}-0.03245 \\
(-3.764)\end{array}$ & 0.176 & 3 \\
\hline San Diego & 2008:3 & $\begin{array}{c}0.150 \\
(3.509)\end{array}$ & $\begin{array}{c}-0.02364 \\
(-3.161)\end{array}$ & 0.117 & 3 \\
\hline San Francisco & 2008:3 & $\begin{array}{c}0.166 \\
(3.769)\end{array}$ & $\begin{array}{c}-0.03717 * * \\
(-4.402)\end{array}$ & 0.182 & 6 \\
\hline Seattle & 2008:8 & $\begin{array}{c}0.17035 \\
(3.587)\end{array}$ & $\begin{array}{c}-0.04463 * * \\
(-4.271)\end{array}$ & 0.232 & 4 \\
\hline Tampa & 2008:3 & $\begin{array}{c}0.174 \\
(2.936)\end{array}$ & $\begin{array}{c}-0.03424 \ddagger \\
(-4.034)\end{array}$ & 0.157 & 7 \\
\hline Washington & 2008:3 & $\begin{array}{c}0.123 \\
(3.901)\end{array}$ & $\begin{array}{c}-0.05131^{* *} \\
(-4.538)\end{array}$ & 0.183 & 8 \\
\hline US & 2008:3 & $\begin{array}{c}0.141 \\
(3.833)\end{array}$ & $\begin{array}{c}-0.03512 \ddagger \\
(-4.181)\end{array}$ & 0.185 & 5 \\
\hline
\end{tabular}

Note: $\quad$ The test statistics for Perron and Vogelsang (1992) are as follows: * 1-percent (-4.97), ${ }^{* *}$ 5-percent (-4.27), and $\neq 10$-percent (-3.86). 
Table 7: Clemente-Montanes-Reyes Test Results for the Innovative Outlier (IO) Model

\begin{tabular}{|c|c|c|c|c|c|c|c|}
\hline MSA & TB1 & TB2 & DU1 & DU2 & Test Statistic & Constant & Lag \\
\hline Atlanta & 1992:10 & 2008:8 & $\begin{array}{c}-0.124 \\
(-2.360)\end{array}$ & $\begin{array}{c}0.354 \\
(4.655)\end{array}$ & $\begin{array}{c}-0.060 \\
(-4.378)\end{array}$ & 0.373 & 2 \\
\hline Boston & 1992:11 & 2008:3 & $\begin{array}{c}-0.121 \\
(-2.531)\end{array}$ & $\begin{array}{c}0.105 \\
(3.455)\end{array}$ & $\begin{array}{l}-0.038 \\
(-4.818)\end{array}$ & 0.284 & 7 \\
\hline Charlotte & 2000:10 & 2008:3 & $\begin{array}{c}0.113 \\
(3.485)\end{array}$ & $\begin{array}{c}0.327 \\
(5.000)\end{array}$ & $\begin{array}{l}-0.065^{*} \\
(-6.090)\end{array}$ & 0.244 & 8 \\
\hline Chicago & 1993:9 & 2008:3 & $\begin{array}{c}-0.174 \\
(-2.705)\end{array}$ & $\begin{array}{c}0.335 \\
(4.705)\end{array}$ & $\begin{array}{l}-0.078 \neq \\
(-5.253)\end{array}$ & 0.586 & 9 \\
\hline Cleveland & 1992:10 & 2008:3 & $\begin{array}{c}-0.099 \\
(-1.597)\end{array}$ & $\begin{array}{c}0.123 \\
(3.036)\end{array}$ & $\begin{array}{c}-0.040 \\
(-3.618)\end{array}$ & 0.312 & 11 \\
\hline Dallas & 2004:2 & 2008:3 & $\begin{array}{c}-0.076 \\
(-2.361)\end{array}$ & $\begin{array}{c}0.175 \\
(4.043)\end{array}$ & $\begin{array}{c}-0.053 \\
(-4.479)\end{array}$ & 0.319 & 3 \\
\hline Denver & 2000:11 & 2008:8 & $\begin{array}{c}0.085 \\
(2.920)\end{array}$ & $\begin{array}{c}0.162 \\
(3.253)\end{array}$ & $\begin{array}{c}-0.047 \\
(-4.217)\end{array}$ & 0.167 & 3 \\
\hline Detroit & 2000:9 & 2008:3 & $\begin{array}{c}0.106 \\
(2.521)\end{array}$ & $\begin{array}{c}0.240 \\
(3.131)\end{array}$ & $\begin{array}{c}-0.041 \\
(-4.193)\end{array}$ & 0.204 & 3 \\
\hline Las Vegas & 1993;4 & 2008:3 & $\begin{array}{c}-0.105 \\
(-2.053)\end{array}$ & $\begin{array}{c}0.432 \\
(5.075)\end{array}$ & $\begin{array}{l}-0.060^{*} \\
(-6.008)\end{array}$ & 0.406 & 10 \\
\hline Los Angeles & 1994:3 & 2008:3 & $\begin{array}{c}-0.206 \\
(-4.367)\end{array}$ & $\begin{array}{c}0.340 \\
(5.545)\end{array}$ & $\begin{array}{l}-0.055 \neq \\
(-5.446)\end{array}$ & 0.518 & 3 \\
\hline Miami & 2001:11 & 2008:3 & $\begin{array}{c}-0.111 \\
(-2.849)\end{array}$ & $\begin{array}{c}0.270 \\
(3.991)\end{array}$ & $\begin{array}{c}-0.045 \\
(-4.555)\end{array}$ & 0.308 & 7 \\
\hline Minneapolis & 2001:1 & 2008:3 & $\begin{array}{c}0.089 \\
(2.916)\end{array}$ & $\begin{array}{c}0.172 \\
(3.372)\end{array}$ & $\begin{array}{l}-0.070 \\
(-4.478)\end{array}$ & 0.209 & 9 \\
\hline New York & 1992:8 & 2008:8 & $\begin{array}{c}-0.231 \\
(-3.503)\end{array}$ & $\begin{array}{c}0.163 \\
(3.725)\end{array}$ & $\begin{array}{c}-0.047 \\
(-4.604)\end{array}$ & 0.496 & 7 \\
\hline Phoenix & 1992:4 & 2008:3 & $\begin{array}{c}-0.153 \\
(-2.484)\end{array}$ & $\begin{array}{c}0.251 \\
(5.110)\end{array}$ & $\begin{array}{c}-0.055^{* *} \\
(-5.906)\end{array}$ & 0.373 & 7 \\
\hline Portland & 2000:11 & 2008:3 & $\begin{array}{c}0.093 \\
(2.926)\end{array}$ & $\begin{array}{c}0.165 \\
(3.600)\end{array}$ & $\begin{array}{c}-0.051 \\
(-5.105)\end{array}$ & 0.237 & 5 \\
\hline San Diego & 1994:3 & 2008:3 & $\begin{array}{c}-0.163 \\
(-3.998)\end{array}$ & $\begin{array}{c}0.299 \\
(5.347)\end{array}$ & $\begin{array}{c}-0.050 \\
(-5.080)\end{array}$ & 0.385 & 3 \\
\hline San Francisco & 1992:10 & 2008:3 & $\begin{array}{c}-0.064 \\
(-1.449)\end{array}$ & $\begin{array}{c}0.194 \\
(4.358)\end{array}$ & $\begin{array}{c}-0.041 \\
(-4.922)\end{array}$ & 0.258 & 6 \\
\hline Seattle & 1994:2 & 2008:8 & $\begin{array}{c}-0.061 \\
(-1.854)\end{array}$ & $\begin{array}{c}0.207 \\
(4.040)\end{array}$ & $\begin{array}{c}-0.052 \\
(-4.663)\end{array}$ & 0.320 & 4 \\
\hline Tampa & 1992:8 & 2008:3 & $\begin{array}{c}-0.152 \\
(-2.412)\end{array}$ & $\begin{array}{c}0.262 \\
(3.808)\end{array}$ & $\begin{array}{c}-0.046 \\
(-4.753)\end{array}$ & 0.353 & 7 \\
\hline Washington & 1992:10 & 2008:3 & $\begin{array}{c}-0.098 \\
(-2.349)\end{array}$ & $\begin{array}{c}0.165 \\
(4.681)\end{array}$ & $\begin{array}{l}-0.066 \neq \\
(-5.269)\end{array}$ & 0.328 & 8 \\
\hline US & 1992:8 & 2008:3 & $\begin{array}{c}-0.115 \\
(-2.639)\end{array}$ & $\begin{array}{c}0.194 \\
(4.668)\end{array}$ & $\begin{array}{c}-0.047 \\
(-4.973)\end{array}$ & 0.356 & 5 \\
\hline
\end{tabular}


Table 8: $\quad$ Bai-Perron Estimates of Break Dates

\begin{tabular}{|c|c|c|c|}
\hline MSA & TB1 & TB2 & TB3 \\
\hline Atlanta & $\begin{array}{c}2008: 4 \\
(2006: 3-2008: 6)\end{array}$ & & \\
\hline Boston & $\begin{array}{c}2000: 11 \\
(1997: 2-2002: 10)\end{array}$ & $\begin{array}{c}2008: 4 \\
(2005: 9-2008: 10)\end{array}$ & \\
\hline Charlotte & $\begin{array}{c}2008: 04 \\
(2004: 9-2008: 5)\end{array}$ & & \\
\hline Chicago & $\begin{array}{c}2008: 4 \\
(2003: 10-2008: 07)\end{array}$ & & \\
\hline Cleveland & $\begin{array}{c}1994: 3 \\
(1994: 2-1994: 11)\end{array}$ & $\begin{array}{c}2001: 7 \\
(2000: 10-2001: 10)\end{array}$ & $\begin{array}{c}2008: 4 \\
(2007: 9-2008: 8)\end{array}$ \\
\hline Dallas & $\begin{array}{c}2001: 12 \\
(2001: 10-2002: 5)\end{array}$ & $\begin{array}{c}2008: 4 \\
(2006: 1-2008: 6)\end{array}$ & \\
\hline Denver & $\begin{array}{c}\text { 1998:10 } \\
(1998: 3-1998: 12)\end{array}$ & $\begin{array}{c}2001: 12 \\
(2001: 11-2002: 7)\end{array}$ & $\begin{array}{c}2008: 9 \\
(2005: 12-2008: 10)\end{array}$ \\
\hline Detroit & $\begin{array}{c}2000: 10 \\
(1998: 12-2001: 5)\end{array}$ & $\begin{array}{c}2008: 04 \\
(2006: 7-2008: 5)\end{array}$ & \\
\hline Las Vegas & $\begin{array}{c}2008: 4 \\
(2007: 2-2008: 5)\end{array}$ & & \\
\hline Los Angeles & $\begin{array}{c}1994: 3 \\
(1993: 11-1994: 8)\end{array}$ & $\begin{array}{c}\text { 2008:4 } \\
(2007: 9-2008: 6)\end{array}$ & \\
\hline Miami & $\begin{array}{c}1994: 4 \\
(1994: 2-1996: 11)\end{array}$ & $\begin{array}{c}2008: 4 \\
(2006: 6-2008: 6)\end{array}$ & \\
\hline Minneapolis & $\begin{array}{c}2008: 2 \\
(2006: 11-2008: 7)\end{array}$ & & \\
\hline New York & $\begin{array}{c}1994: 3 \\
(1993: 6-1996: 9)\end{array}$ & $\begin{array}{c}2004: 3 \\
(2003: 3-2004: 8)\end{array}$ & $\begin{array}{c}2008: 4 \\
(2008: 02-2008: 5)\end{array}$ \\
\hline Phoenix & $\begin{array}{c}2008: 4 \\
(2006: 8-2008: 6)\end{array}$ & & \\
\hline Portland & $\begin{array}{c}2001: 1 \\
(1998: 7-2001: 3)\end{array}$ & $\begin{array}{c}2004: 3 \\
(2004: 2-2005: 4)\end{array}$ & $\begin{array}{c}2008: 4 \\
(2006: 10-2008: 6)\end{array}$ \\
\hline San Diego & $\begin{array}{c}1994: 3 \\
(1994: 1-1995: 3)\end{array}$ & $\begin{array}{c}1999: 12 \\
(1993: 9-2000: 7)\end{array}$ & $\begin{array}{c}\text { 2008:4 } \\
(2007: 11-2008: 6)\end{array}$ \\
\hline San Francisco & $\begin{array}{c}2000: 12 \\
(1997: 8-2001: 8)\end{array}$ & $\begin{array}{c}2004: 3 \\
(2003: 11-2004: 11)\end{array}$ & $\begin{array}{c}2008: 04 \\
(2005: 09-2008: 06)\end{array}$ \\
\hline Seattle & $\begin{array}{c}2008: 9 \\
(2005: 1-2008: 10)\end{array}$ & & \\
\hline Tampa & $\begin{array}{c}2008: 4 \\
(2005: 7-2008: 6)\end{array}$ & & \\
\hline Washington & $\begin{array}{c}2008: 4 \\
(2005: 2-2008: 6)\end{array}$ & & \\
\hline U.S. & $\begin{array}{c}2008: 4 \\
(2004: 9-2008: 6)\end{array}$ & & \\
\hline
\end{tabular}

Note: $\quad$ The break dates are chosen based on BIC statistic, assuming a maximum of five breaks. The 95 percent confidence interval for the estimated break points appears in parentheses under the break points, constructed using the Bai and Perron $(1998,2003)$ method. The confidence intervals reflect the 95-percent confidence level. 
Table 9: $\quad$ Bai-Perron OLS Estimates of the Regimes

\begin{tabular}{|c|c|c|c|c|c|c|c|c|}
\hline \multirow[b]{2}{*}{ MSA } & \multicolumn{2}{|c|}{ Regime 1} & \multicolumn{2}{|c|}{ Regime 2} & \multicolumn{2}{|c|}{ Regime 3} & \multicolumn{2}{|c|}{ Regime 4} \\
\hline & $\mu_{1}$ & $\rho_{1}$ & $\mu_{2}$ & $\rho_{2}$ & $\mu_{3}$ & $\rho_{3}$ & $\mu_{4}$ & $\rho_{4}$ \\
\hline Atlanta & $\begin{array}{l}0.115 \\
(1.56)\end{array}$ & $\begin{array}{c}.974 \\
(59.36)\end{array}$ & $\begin{array}{c}.909 \\
(4.52)\end{array}$ & $\begin{array}{c}.909 \\
(42.20)\end{array}$ & & & & \\
\hline Boston & $\begin{array}{l}-0.042 \\
(-1.15)\end{array}$ & $\begin{array}{c}1.000 \\
(148.35)\end{array}$ & $\begin{array}{c}.306 \\
(3.25)\end{array}$ & $\begin{array}{c}.938 \\
(46.50)\end{array}$ & $\begin{array}{c}.636 \\
(4.32)\end{array}$ & $\begin{array}{c}.913 \\
(42.81)\end{array}$ & & \\
\hline Charlotte & $\begin{array}{c}0.056 \\
(.97)\end{array}$ & $\begin{array}{c}.988 \\
(80.99)\end{array}$ & $\begin{array}{c}1.05 \\
(6.25)\end{array}$ & $\begin{array}{c}.908 \\
(57.33)\end{array}$ & & & & \\
\hline Chicago & $\begin{array}{l}0.100 \\
(1.22)\end{array}$ & $\begin{array}{c}.981 \\
(70.11)\end{array}$ & $\begin{array}{c}.932 \\
(4.46)\end{array}$ & $\begin{array}{c}.908 \\
(41.43)\end{array}$ & & & & \\
\hline Cleveland & $\begin{array}{c}.955 \\
(2.27)\end{array}$ & $\begin{array}{c}.873 \\
(15.39)\end{array}$ & $\begin{array}{c}.315 \\
(3.17)\end{array}$ & $\begin{array}{c}.925 \\
(44.45)\end{array}$ & $\begin{array}{c}.889 \\
(3.62)\end{array}$ & $\begin{array}{c}.848 \\
(19.82)\end{array}$ & $\begin{array}{c}.683 \\
(2.89)\end{array}$ & $\begin{array}{c}.918 \\
(31.70)\end{array}$ \\
\hline Dallas & $\begin{array}{c}-.436 \\
(-2.45)\end{array}$ & $\begin{array}{c}1.135 \\
(26.25)\end{array}$ & $\begin{array}{l}-.010 \\
(-.097)\end{array}$ & $\begin{array}{c}.997 \\
(49.94)\end{array}$ & $\begin{array}{c}.743 \\
(5.11)\end{array}$ & $\begin{array}{c}.907 \\
(46.52)\end{array}$ & & \\
\hline Denver & $\begin{array}{l}.025 \\
(.29)\end{array}$ & $\begin{array}{c}.989 \\
(46.57)\end{array}$ & $\begin{array}{c}-.549 \\
(-4.68)\end{array}$ & $\begin{array}{c}1.220 \\
(30.96)\end{array}$ & $\begin{array}{l}.087 \\
(.77)\end{array}$ & $\begin{array}{c}.980 \\
(46.23)\end{array}$ & $\begin{array}{l}1.357 \\
(5.96)\end{array}$ & $\begin{array}{c}.843 \\
(30.86)\end{array}$ \\
\hline Detroit & $\begin{array}{l}.213 \\
(.26)\end{array}$ & $\begin{array}{c}.988 \\
(76.81)\end{array}$ & $\begin{array}{c}.705 \\
(3.02)\end{array}$ & $\begin{array}{c}.902 \\
(26.46)\end{array}$ & $\begin{array}{c}.814 \\
(3.38)\end{array}$ & $\begin{array}{c}.939 \\
(49.76)\end{array}$ & & \\
\hline Las Vegas & $\begin{array}{c}.099 \\
(1.27)\end{array}$ & $\begin{array}{l}.980 \\
(66.51)\end{array}$ & $\begin{array}{l}1.021 \\
(7.39)\end{array}$ & $\begin{array}{c}.927 \\
(83.16)\end{array}$ & & & & \\
\hline Los Angeles & $\begin{array}{c}.966 \\
(3.58)\end{array}$ & $\begin{array}{c}.896 \\
(28.83)\end{array}$ & $\begin{array}{c}.203 \\
(2.65)\end{array}$ & $\begin{array}{c}.962 \\
(75.41)\end{array}$ & $\begin{array}{l}1.142 \\
(6.80)\end{array}$ & $\begin{array}{c}.902 \\
(57.64)\end{array}$ & & \\
\hline Miami & $\begin{array}{l}1.282 \\
(2.91)\end{array}$ & $\begin{array}{c}.855 \\
(17.07)\end{array}$ & $\begin{array}{l}1.512 \\
(2.35)\end{array}$ & $\begin{array}{c}.782 \\
(8.75)\end{array}$ & $\begin{array}{c}.151 \\
(1.36)\end{array}$ & $\begin{array}{c}.967 \\
(44.76)\end{array}$ & $\begin{array}{c}.962 \\
(5.10)\end{array}$ & $\begin{array}{c}.911 \\
(48.29)\end{array}$ \\
\hline Minneapolis & $\begin{array}{l}.057 \\
(.29)\end{array}$ & $\begin{array}{c}.984 \\
(67.09)\end{array}$ & $\begin{array}{c}.502 \\
(3.00)\end{array}$ & $\begin{array}{c}.0 .928 \\
(37.35)\end{array}$ & & & & \\
\hline New York & $\begin{array}{c}.835 \\
(2.73)\end{array}$ & $\begin{array}{c}.903 \\
(24.51)\end{array}$ & $\begin{array}{c}.208 \\
(1.84)\end{array}$ & $\begin{array}{c}.963 \\
(51.83)\end{array}$ & $\begin{array}{c}.859 \\
(3.23)\end{array}$ & $\begin{array}{c}.813 \\
(14.85)\end{array}$ & $\begin{array}{c}.786 \\
(4.68)\end{array}$ & $\begin{array}{c}.914 \\
(44.66)\end{array}$ \\
\hline Phoenix & $\begin{array}{l}.0498 \\
(1.01)\end{array}$ & $\begin{array}{c}.988 \\
(85.66)\end{array}$ & $\begin{array}{c}.927 \\
(6.66)\end{array}$ & $\begin{array}{c}.900 \\
(55.89)\end{array}$ & & & & \\
\hline Portland & $\begin{array}{l}.084 \\
(.81)\end{array}$ & $\begin{array}{c}.982 \\
(45.72)\end{array}$ & $\begin{array}{c}.878 \\
(3.97)\end{array}$ & $\begin{array}{c}.891 \\
(30.18)\end{array}$ & $\begin{array}{c}.367 \\
(1.82)\end{array}$ & $\begin{array}{c}.923 \\
(25.81)\end{array}$ & $\begin{array}{c}.900 \\
(5.49)\end{array}$ & $\begin{array}{c}.911 \\
(52.84)\end{array}$ \\
\hline San Diego & $\begin{array}{c}.607 \\
(2.21)\end{array}$ & $\begin{array}{c}.921 \\
(24.24)\end{array}$ & $\begin{array}{l}.020 \\
(.29)\end{array}$ & $\begin{array}{c}.982 \\
(72.21)\end{array}$ & $\begin{array}{c}.362 \\
(2.68)\end{array}$ & $\begin{array}{c}.924 \\
(31.03)\end{array}$ & $\begin{array}{c}.888 \\
(6.39)\end{array}$ & $\begin{array}{c}.914 \\
(61.91)\end{array}$ \\
\hline San Francisco & $\begin{array}{l}-.002 \\
(-.04)\end{array}$ & $\begin{array}{r}.998 \\
(79.81)\end{array}$ & $\begin{array}{r}.534 \\
(3.74)\end{array}$ & $\begin{array}{r}.918 \\
(36.83)\end{array}$ & $\begin{array}{r}.515 \\
(2.30)\end{array}$ & $\begin{array}{r}.884 \\
(18.63)\end{array}$ & $\begin{array}{r}.863 \\
(6.31)\end{array}$ & $\begin{array}{r}.913 \\
(61.06)\end{array}$ \\
\hline Seattle & $\begin{array}{l}.071 \\
(.28)\end{array}$ & $\begin{array}{c}.986 \\
(78.94)\end{array}$ & $\begin{array}{c}1.34 \\
(6.73)\end{array}$ & $\begin{array}{c}.854 \\
(37.89)\end{array}$ & & & & \\
\hline Tampa & $\begin{array}{l}.047 \\
(.95)\end{array}$ & $\begin{array}{c}.989 \\
(94.77)\end{array}$ & $\begin{array}{c}.985 \\
(5.82)\end{array}$ & $\begin{array}{c}.912 \\
(56.45)\end{array}$ & & & & \\
\hline Washington & $\begin{array}{c}.054 \\
(1.09)\end{array}$ & $\begin{array}{c}.983 \\
(73.51)\end{array}$ & $\begin{array}{l}.616 \\
(5.12)\end{array}$ & $\begin{array}{c}.900 \\
(42.91)\end{array}$ & & & & \\
\hline U.S. & $\begin{array}{l}.051 \\
(-.37)\end{array}$ & $\begin{array}{c}.989 \\
(90.02)\end{array}$ & $\begin{array}{c}.846 \\
(6.41)\end{array}$ & $\begin{array}{c}.910 \\
(58.74)\end{array}$ & & & & \\
\hline
\end{tabular}

Note: Figures in parentheses are estimated t-statistics. The number of regimes for each MSA is selected according to the results in Table 8. $\mu_{i}$ is the estimated mean for the regime $i$, and $\rho_{i}$ is the corresponding estimated first-order autoregressive parameter. Figures in parentheses are estimated $t$ statistics. The first regime begins in 1991:01 (except for Dallas, which starts in January 2000) and the last regime ends in 2012:02. 